Article

\title{
Redox-Dependent Copper Ion Modulation of Amyloid- $\beta$ (1-42) Aggregation In Vitro
}

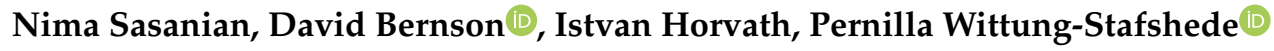 \\ and Elin K. Esbjörner* \\ Department of Biology and Biological Engineering, Chalmers University of Technology, \\ 41296 Gothenburg, Sweden; sasanian@chalmers.se (N.S.); david.bernson@chalmers.se (D.B.); \\ istvanh@chalmers.se (I.H.); pernilla.wittung@chalmers.se (P.W.-S.) \\ * Correspondence: eline@chalmers.se; Tel.: +46-31-772-51-20
}

Received: 15 May 2020; Accepted: 16 June 2020; Published: 18 June 2020

check for updates

\begin{abstract}
Plaque deposits composed of amyloid- $\beta(\mathrm{A} \beta)$ fibrils are pathological hallmarks of Alzheimer's disease (AD). Although copper ion dyshomeostasis is apparent in AD brains and copper ions are found co-deposited with $\mathrm{A} \beta$ peptides in patients' plaques, the molecular effects of copper ion interactions and redox-state dependence on $\mathrm{A} \beta$ aggregation remain elusive. By combining biophysical and theoretical approaches, we here show that $\mathrm{Cu}^{2+}$ (oxidized) and $\mathrm{Cu}^{+}$(reduced) ions have opposite effects on the assembly kinetics of recombinant $A \beta(1-42)$ into amyloid fibrils in vitro. $\mathrm{Cu}^{2+}$ inhibits both the unseeded and seeded aggregation of $\mathrm{A} \beta(1-42)$ at $\mathrm{pH}$ 8.0. Using mathematical models to fit the kinetic data, we find that $\mathrm{Cu}^{2+}$ prevents fibril elongation. The $\mathrm{Cu}^{2+}$-mediated inhibition of $\mathrm{A} \beta$ aggregation shows the largest effect around $\mathrm{pH} 6.0$ but is lost at $\mathrm{pH} 5.0$, which corresponds to the $\mathrm{pH}$ in lysosomes. In contrast to $\mathrm{Cu}^{2+}, \mathrm{Cu}^{+}$ion binding mildly catalyzes the $\mathrm{A} \beta(1-42)$ aggregation via a mechanism that accelerates primary nucleation, possibly via the formation of $\mathrm{Cu}^{+}$-bridged $\mathrm{A} \beta(1-42)$ dimers. Taken together, our study emphasizes redox-dependent copper ion effects on A $\beta(1-42)$ aggregation and thereby provides further knowledge of putative copper-dependent mechanisms resulting in $\mathrm{AD}$.
\end{abstract}

Keywords: amyloid; amyloid- $\beta$; copper; aggregation; kinetics; inhibition; Alzheimer's disease

\section{Introduction}

Alzheimer's disease (AD) is an incurable and fatal neurodegenerative condition resulting from the progressive death of neurons in the brain and the concomitant loss of cognitive functions, and which is associated with protein aggregation and deposition [1]. AD is the most common form of adult dementia, mainly afflicting people over the age of 65 [2]. The prevalence of the disease is expected to rise worldwide due to population ageing, and unless there are new disease-modifying treatments, a projected 130 million people may be affected by 2050 [3].

$\mathrm{AD}$ is pathologically, genetically, and biochemically strongly linked to amyloid formation and the deposition of amyloid- $\beta$ (A $\beta$ ) peptides into extracellular senile plaques [1,4,5]. A $\beta$ peptides are generated by the proteolytic cleavage of the so-called amyloid precursor protein (APP) by $\beta$ - and $\gamma$-secretases [6]. This occurs in the acidic environment of endosomes [7], where A $\beta$ can also aggregate [8] and accumulate during early neuronal dysfunction and prior to the deposition of extracellular plaques [9]. A $\beta$ peptides can differ in size. Even though the 40 amino acid $A \beta(1-40)$ variant is most abundant, the two residues longer $A \beta(1-42)$ variant is more aggregation-prone [10] and also the main protein constituent of extracellular amyloid plaques [11]. Probing A $\beta(1-42)$ self-assembly mechanisms and the influence of biological as well as pharmacological extrinsic aggregation modifiers is therefore important. Recent progress in the development of models that mechanistically describe 
how amyloid fibrils are formed [12,13] has enabled the determination of rate constants for different microscopic reaction steps (Figure 1a) through the analysis of amyloid kinetics data. In the case of $A \beta(1-42)$, this analysis has revealed that secondary nucleation is the dominant mechanism of new aggregate formation [14]. The same methods have also been used to rationalize the inhibitory effects of chaperones [15] and antibodies [16], and the catalytic effect of small molecules [17] and lipids [18].

Metal ions and imbalances in metal ion homeostasis are considered to play pivotal roles in neurodegeneration [19-21], contributing to oxidative stress responses [22,23] as well as directly to protein aggregation [24-27]. Along this line, metal ions-including iron, zinc, and copper $(\mathrm{Cu})$-are found to co-deposit with $A \beta$ fibrils in the core of plaques [28-30], and interactions between $A \beta$ and redox-active metal ions (e.g., Fe and $\mathrm{Cu}$ ) can drive the production of hydrogen peroxide [31-33], superoxide anions [34], and hydroxyl radicals [35], thus potentially contributing directly to the oxidative stress that is observed in AD [36]. Based on this type of data, metal chelators have been proposed as future AD therapeutics [37], and favorable effects on $A \beta$ accumulation and toxicity both in vitro and in vivo have been reported [38]. However, the literature on how metal ions affect $\mathrm{A} \beta$ peptide aggregation is inconclusive in many respects, with reports on both enhancing and inhibitory effects.

Dysregulated $\mathrm{Cu}$ homeostasis has been associated with AD [19,39-42] and is manifested as elevated $\mathrm{Cu}$ levels in plasma $[19,41]$ but diminished levels of $\mathrm{Cu}$ in the brain, especially in the amygdala and hippocampal regions [40]. The concentrations of total $\mathrm{Cu}$ in amyloid plaques $(400 \mu \mathrm{M})$ and the synaptic cleft $(15 \mu \mathrm{M})$ are higher than the extracellular concentration in the brain $(0.2-1.7 \mu \mathrm{M})$ [21]; the former may contribute to the reported imbalances. The redox ability of $\mathrm{Cu}$ enables it to cycle between $\mathrm{Cu}^{+}$and $\mathrm{Cu}^{2+}$ states, underlying its function in many enzymes. The $\mathrm{Cu}^{2+}$ form is predominant under oxidizing conditions which also prevail in many locations where $A \beta$ is abundant, such as the extracellular space and the oxidizing and low $\mathrm{pH}$ environment of endosomes and lysosomes [43]. In the context of $\mathrm{AD}, \mathrm{Cu}^{2+}$ is therefore the most frequently studied redox form. $\mathrm{Cu}^{+}$, which is mainly bound to proteins in the cytosol where the environment is highly reducing, has been less explored, but the high reduction potential found for $C u$ when bound to $A \beta$ suggests that $C u^{+}: A \beta$ may be present at oxidative stress and/or pathological conditions. Probing the effects of both the redox states of $\mathrm{Cu}$ on $\mathrm{A} \beta$ aggregation is therefore important.

There are several biophysical studies on the effect of $\mathrm{Cu}^{2+}$ on $\mathrm{A} \beta$ aggregation, but the results are divergent. The majority of papers suggest that $\mathrm{Cu}^{2+}$ inhibits $\mathrm{A} \beta$ aggregation [44-50], a property shared with, for example, $\mathrm{Zn}^{2+}$ [51]. However, accelerating effects have also been suggested [52-54], for example under mildly acidic conditions [24]. $\mathrm{Cu}^{2+}$ has also been reported to selectively induce the formation of cytotoxic $\mathrm{A} \beta$ (1-42) oligomers under conditions where $\mathrm{Zn}^{2+}$ did not [55], thereby putatively contributing specifically to toxicity. In addition, $\mathrm{Cu}^{2+}$ have been reported to modulate $\mathrm{A} \beta$ integrity, for example by inducing the aggregation-inhibitory dityrosine dimerization in the presence of $\mathrm{H}_{2} \mathrm{O}_{2}$ or ascorbate [52], or by mediating hydrolytic cleavage in presence of large excess of antioxidants [56], emphasizing that this metal has multiple effects. The role of $\mathrm{Cu}^{+}$in $\mathrm{A} \beta(1-42)$ aggregation has been less studied, but one report suggested, based on transmission electron microscopy, that both $\mathrm{Cu}^{+}$and $\mathrm{Cu}^{2+}$ could prevent $\mathrm{A} \beta$ fibril formation [57].

$\mathrm{A} \beta$ peptides coordinate both $\mathrm{Cu}^{2+}$ and $\mathrm{Cu}^{+}$ions via $\mathrm{N}$-terminal residues (Figure $1 \mathrm{a}$ ), but there is significant disparity in their binding affinities and exact coordination geometries. For $\mathrm{Cu}^{2+}$, dissociation constants are reportedly in the picomolar to low nanomolar range [58], and both 1:1 and 2:1 binding stoichiometries have been reported, albeit with significantly weaker binding of the second $\mathrm{Cu}^{2+}$ ion [59-62]. A $\beta$ binds $\mathrm{Cu}^{2+}$ primarily via 3N1O coordination, resulting in the formation of an N-terminal loop via the engagement of the N-terminus, the carboxyl group on Asp1, and two imidazole nitrogens (on His6, His13, or His 14) or Asp1 and all three histidines (Figure 1b,c) [60,63-66]. The binding affinity [67], coordination geometry [64,66,68,69], and stoichiometry [70] of $\mathrm{Cu}^{2+}$ is sensitive to $\mathrm{pH}$. A loss of coordination or weak affinity at $\mathrm{pH} 5.0$ has been reported [67], as well as the successive transition towards $4 \mathrm{~N}$ coordination above $\mathrm{pH} 8.0$ [66]. Probing how A $\beta$ aggregation proceeds as a function of $\mathrm{pH}$ is therefore important, particularly in light of the pathological aggregation of $\mathrm{A} \beta(1-42)$ 
in endolysosomes [8,9] where metals, including $\mathrm{Cu}$, are conspicuously abundant [71]. $\mathrm{Cu}^{2+}$ can bind monomeric, oligomeric, and fibrillar $A \beta$ states with comparable affinity $[63,64]$, and it was reported that the level of $\mathrm{Cu}^{2+}$ bound to $\mathrm{A} \beta(1-40)$ did not change during aggregation [63]. This is consistent with the fact that residues 1-14 of $\mathrm{A} \beta(1-42)$ (to which $\mathrm{Cu}$ coordinates) remain flexible and are not incorporated in the amyloid fibril core (Figure $1 b$ ). $\mathrm{Cu}^{+}$binds $\mathrm{A} \beta$ in a bidentate linear $2 \mathrm{~N}$ coordination engaging two N-imidazoles (Figure 1d), most likely His13 and His14 [65]. Thus, $\mathrm{Cu}^{+}$binding can occur without loop formation, rendering the $\mathrm{N}$-terminus more flexible compared to when binding $\mathrm{Cu}^{2+}$. The affinity of $\mathrm{Cu}^{+}$is reported to be in the femtomolar range, suggesting that $\mathrm{Cu}^{+}$binds tighter than $\mathrm{Cu}^{2+}$ to $\mathrm{A} \beta[65,72]$. Notably, there are no reports on the interactions of $\mathrm{Cu}^{+}$with $\mathrm{A} \beta$ oligomers or fibrils.

a

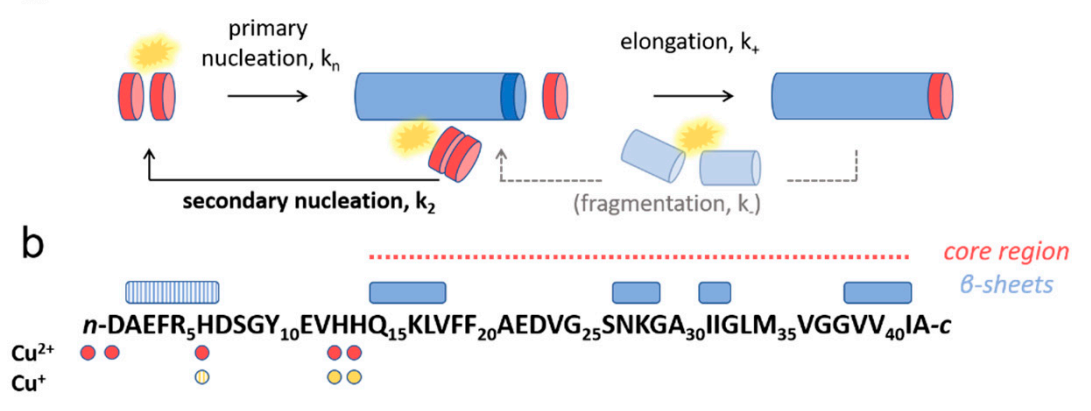

C<smiles>O=[N+]([O-])C(N1CCNC1)(N1CCNC1)N1CCNC1</smiles>

d

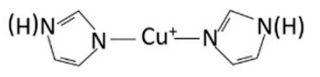

Figure 1. Amyloid formation and copper coordination by amyloid- $\beta$ (A $\beta)(1-42)$. (a) Schematic illustration of the reaction steps involved in nucleated amyloid fibril formation, including primary nucleation, elongation, secondary nucleation, and fragmentation. The kinetics of the aggregation of $A \beta(1-42)$ alone is dominated by the generation of new aggregates through secondary nucleation (bold text), whereas fragmentation (shadowed) plays no significant role. (b) A $\beta(1-42)$ primary structure with proposed amyloid fibril core $\beta$-sheets, according to recent high-resolution structural models indicated by blue boxes $[73,74]$. Note that one model reports $\beta$-sheet formation also at the N-terminus, albeit without participation in the formation of the core. Coordination sites for $\mathrm{Cu}^{2+}$ and $\mathrm{Cu}^{+}$are indicated by red and yellow dots, respectively. (c,d) Consensus coordination mode of (c) $\mathrm{Cu}^{2+}$ and (d) $\mathrm{Cu}^{+}$, with respective ligation partners [65].

In this study, we revisit the question of how $\mathrm{Cu}$ influences $\mathrm{A} \beta(1-42)$ amyloid formation, using Thioflavin-T assays with monomeric recombinant peptides as the starting material [75], a procedure that we [18] and others [14] have shown to result in highly reproducible aggregation kinetics. Moreover, by taking advantage of recent theoretical developments to model protein aggregation kinetics [14], enabling detailed molecular and mechanistic understanding of amyloid formation catalysis and inhibition as mentioned above, this study reveals new quantitative information on how $\mathrm{Cu}^{2+}$ and $\mathrm{Cu}^{+}$ affect discrete microscopic events during $A \beta(1-42)$ self-assembly, resulting in different macroscopic effects on aggregation by the two forms of $\mathrm{Cu}$. We also explore the $\mathrm{pH}$-dependent effects of $\mathrm{Cu}^{2+}$ ions on $\mathrm{A} \beta(1-42)$ aggregation, addressing the pathological consequences of alterations in $\mathrm{pH}$ during endolysosomal processing, which may relate to the earliest $A \beta$ aggregation events $[73,74]$. Our main finding is that $\mathrm{Cu}^{2+}$ and $\mathrm{Cu}^{+}$have opposite effects on $\mathrm{A} \beta(1-42)$ aggregation. $\mathrm{Cu}^{2+}$ primarily interferes with fibril elongation, whereas $\mathrm{Cu}^{+}$instead catalyzes primary nucleation. We discuss the results in relation to the $\mathrm{Cu}$ coordination geometries and the putative effects of $\mathrm{Cu}$ on $\mathrm{A} \beta$-mediated neurotoxicity in the context of $\mathrm{AD}$.

\section{Materials and Methods}

\subsection{Protein Expression and Purification}

Recombinant $\mathrm{A} \beta(1-42)$ was expressed as a fusion protein with the solubility tag $\mathrm{NT}^{*}$ and purified as described in [76,77], but with some modification. The plasmid encoding for NT-A $\beta(1-42)$ (a kind gift from Dr. Henrik Biverstål, Karolinska Institute) was transfected into E. coli (BL21) cells and expressed 
overnight using $0.5 \mathrm{mM}$ IPTG induction at $\mathrm{OD}_{600} \sim 0.7$. Bacterial cells were harvested by centrifugation and lysed in $20 \mathrm{mM}$ Tris- $\mathrm{HCl}, 8 \mathrm{M}$ urea, $\mathrm{pH}$ 8.0, by sonication. The sonicated lysate was filtered through a $0.22 \mu \mathrm{M}$ syringe filter (VWR, Radnor, US) and loaded onto a HisPrep FF 16/10 column (GE Healthcare, Chicago, US) equilibrated with $20 \mathrm{mM}$ Tris-HCl, $8 \mathrm{M}$ urea, $\mathrm{pH}$ 8.0. The NT-A $\beta(1-42)$ was eluted with $300 \mathrm{mM}$ imidazole in the same buffer and then dialyzed against $5 \mathrm{~L} 20 \mathrm{mM}$ sodium phosphate at $4{ }^{\circ} \mathrm{C}$, with $1.5 \mathrm{mM}$ 1,4-dithiothreitol (DTT) and $0.5 \mathrm{mM}$ EDTA, pH 8.0. After $2 \mathrm{hrs}$ of dialysis, 1:20 molar equivalents of tobacco etch virus (TEV) protease (produced as previously described [78]) was added to the NT-A $\beta(1-42)$, followed by quiescent incubation over night at $4{ }^{\circ} \mathrm{C}$. Following the TEV digestion, the solution was injected onto a HiLoad 16/600 Superdex 30 pg (GE Healthcare, Chicago, US) size exclusion column equilibrated with $20 \mathrm{mM}$ sodium phosphate, $\mathrm{pH} 8.0$, and monomeric A $\beta(1-42)$ was isolated as a single peak. The monomeric peptides were immediately aliquoted, freeze dried, and stored at $-20{ }^{\circ} \mathrm{C}$ until further use.

\subsection{A $\beta(1-42)$ Aggregation Assays}

The $A \beta(1-42)$ aggregation was monitored by thioflavin-T (ThT) fluorescence. Prior to each kinetic experiment, lyophilized $\mathrm{A} \beta(1-42)$ was dissolved in $6 \mathrm{M}$ guanidine hydrochloride $(\mathrm{GuHCl})$, followed by incubation on ice for $20 \mathrm{~min}$. The monomeric $A \beta(1-42)$ solution was purified by size-exclusion chromatography using a 10/300 Superdex 75 (GE Healthcare, Chicago, IL, US) column and equilibrated with $20 \mathrm{mM}$ sodium phosphate, $\mathrm{pH}$ 8.0, to minimize isoelectric precipitation and reduce the aggregation rate so that the samples could be transferred to microtiter plates without significant aggregation occurring, following a common experimental protocol $[14,79,80]$. The $A \beta(1-42)$ concentration was determined from the integrated peak area using an extinction coefficient of $\varepsilon_{280}=1280 \mathrm{M}^{-1} \mathrm{~cm}^{-1}$. The monomeric $A \beta(1-42)$ solution was immediately transferred to ice to prevent any aggregation before starting the experiments. The $\mathrm{A} \beta(1-42)$ monomers were diluted in phosphate buffers or citrate-phosphate buffers to obtain a specific solution $\mathrm{pH}$, as indicated in the text and figure legends (see Table S1 for detailed buffer compositions). $5 \mu \mathrm{M}$ thioflavin-T (ThT, Sigma, St. Louis, MO, US) (three times recrystallized in tetrahydrofuran (THF) to remove impurities) was added from a $0.5 \mathrm{mM}$ stock solution. The $\mathrm{A} \beta(1-42)$ solutions were supplemented with $\mathrm{CuCl}_{2}$ (to obtain $\mathrm{Cu}^{2+}$ ) or $\mathrm{CuCl}_{2}$ pre-mixed with a $5 x$ molar excess of freshly prepared 1,4-dithiothreitol (DTT, Sigma, St. Louis, MO, US) to generate $\mathrm{Cu}^{+}$, according to a previously established protocol [81-83]. The peptide solutions were thereafter added to the wells of 96-well black half-area, low binding, transparent bottom microtiter plates (Corning, \#3881, Corning, NY, US). The total volume in each well was always $70 \mu \mathrm{L}$. The plates were sealed with adhesive film (BIO-RAD, Hercules, US) to prevent sample evaporation and the ThT emission was measured from the bottom of the plate using a Fluostar Optima or Fluostar Omega plate reader (BMG Labtech, Ortenberg, Germany ) with a $440 \pm 10 \mathrm{~nm}$ bandpass filter for excitation, and a $490 \pm 10 \mathrm{~nm}$ bandpass filter for emission. All measurements were performed in triplicate $(\mathrm{n}=3)$ and under strictly quiescent conditions (no shaking) at $37^{\circ} \mathrm{C}$ and were repeated at least 3 times.

\subsection{Seeds Preparation}

Fibril seeds for seeded aggregation experiments were formed by setting up the above-described kinetic experiment with $2.6 \mu \mathrm{M} \mathrm{A} \beta(1-42)$ in $20 \mathrm{mM}$ sodium phosphate buffer, $\mathrm{pH} 8.0$, and $5 \mu \mathrm{M}$ ThT. All seeds were prepared in the absence of $\mathrm{Cu}$. The seeds were collected from the wells after the completion of the experiment and transferred into low-binding $1.5 \mathrm{~mL}$ tubes and then added to samples based on the monomer-equivalent concentration.

\subsection{Analysis and Fitting of ThT Kinetic Curves}

Kinetic data acquired in the presence of increasing amounts of $\mathrm{Cu}^{+}$and $\mathrm{Cu}^{2+}$ were analyzed based on the previously described integrated rate laws for $A \beta(1-42)$ amyloid formation and using a model including secondary nucleation $[14,84]$. The theoretical curves of the kinetic evolution of aggregates were globally fitted to the experimental ThT data (see Section 2.2) using the AmyloFit web interface [85] 
to obtain quantitative estimates of the rate constants. For $\mathrm{Cu}^{2+}$, we used a seeded model to determine individually the rate constants for primary nucleation $\left(\mathrm{k}_{\mathrm{n}}\right)$, elongation $\left(\mathrm{k}_{+}\right)$, and secondary nucleation $\left(\mathrm{k}_{2}\right)$, keeping one parameter at a time variable (i.e., dependent on the $\mathrm{Cu}^{2+}$ concentration) and the others as global constants (i.e., independent of the $\mathrm{Cu}^{2+}$ concentration). All the fits were conducted using a 10-basin hop algorithm with errors and using normalized ThT kinetics data, as described by Meisl et al. [85]. For $\mathrm{Cu}^{+}$, we used a non-seeded model to determine the convoluted rate constants $\mathrm{k}_{+} \mathrm{k}_{\mathrm{n}}$ and $\mathrm{k}_{+} \mathrm{k}_{2}$.

\subsection{Dot-Blot Assay}

Dot-blot assays were performed using the anti-amyloid fibril antibody LOC (Millipore, Burlington, MA, US, [86]), specific for amyloid fibrils. $20 \mu \mathrm{L}$ of each sample containing A $\beta(1-42)$ with or without $\mathrm{Cu}^{2+}$ or $\mathrm{Cu}^{+}$was taken directly from the aggregation reactions and added to a 96-well dot-blot hybridization manifold (Scie-plas Ltd., Cambridge, UK). Vacuum pressure was applied to deposit the samples onto an LF-PVDF membrane (Trans-Blot, BIO-RAD, Hercules, CA, US). The membrane was dried and blocked with $30 \mathrm{~mL}$ of $5 \%$ skimmed milk in phosphate buffer saline with Tween-20 (PBS-T) and incubated for $1 \mathrm{~h}$ at room temperature. The membrane was then incubated for $30 \mathrm{~min}$ at room temperature with $30 \mathrm{~mL}$ of a primary antibody $(1: 100,000)$ dissolved in BSA/PBS-T. After three washes (5 min each time) with PBS-T, the membrane was incubated with a 1:20,000 dilution HRP-conjugated goat anti-rabbit secondary antibody (Sigma, St. Louis, MO, US). Thereafter, the membrane was washed three times with PBS-T $(15 \mathrm{~min} \times 1,5 \mathrm{~min} \times 2)$. The resulting dots were developed using an enhanced chemiluminescence solution (ECL, GE healthcare, Chicago, IL, US) together with the chemiluminescence detection system of a ChemiDoc ${ }^{\mathrm{TM}}$ gel scanner (BIO-RAD, Hercules, CA, US). The densiometric analysis was performed using the instrument's built-in software and the region-of-interest function.

\subsection{Transmission Electron Microscopy (TEM)}

TEM images were taken to examine the morphological appearance of $A \beta(1-42)$ amyloid aggregates in the absence and presence of $\mathrm{Cu} .10 \mu \mathrm{L}$ of the sample taken at the end-point of the kinetic aggregation experiment was deposited onto glow-charged, formvar-coated, carbon-stabilized copper EM grids (Agar scientific, S138, Essex, UK) and allowed to settle for $10 \mathrm{~min}$. The grids were thereafter stained with aqueous phosphotungstate (1\% PTA), blotted with filter paper (Whatman, Grade 40, GE Healthcare, Chicago, IL, US), and allowed to dry before imaging [87]. High-contrast images were obtained with a TALOS L120C TEM (Thermo Fisher Scientific, Waltham, MA, US) at an accelerating voltage of $120 \mathrm{kV}$ using a $4 \times 4 \mathrm{k}$ CMOS Ceta camera (Thermo Fisher Scientific, Waltham, MA, US). The magnification was set to $17,500 x-300,000 x$.

\section{Results and Discussion}

\section{1. $\mathrm{Cu}^{2+}$ Inhibits $A \beta(1-42)$ Amyloid Formation}

To explore the effect of $\mathrm{Cu}^{2+}$ ions on the aggregation of $\mathrm{A} \beta(1-42)$ into fibrils, we used Thioflavin-T (ThT) fluorescence to measure the amyloid formation kinetics. ThT binds to the regular $\beta$-sheet structure of amyloid fibrils (but does not associate with unstructured oligomers), and this increases dramatically its fluorescence quantum yield [88]. At stoichiometric amounts, ThT has been shown to have a negligible effect on the aggregation kinetics [14], and it is therefore a good in situ reporter of amyloid fibril formation. Recombinant $A \beta(1-42)$ was monomerized by size exclusion chromatography (SEC) (Figure S1) immediately prior to each experiment to avoid the presence of pre-formed aggregates $[75,85]$. The purified peptides were allowed to aggregate under quiescent conditions in the absence or presence of $\mathrm{CuCl}_{2}$, such that the experiment probed the $\mathrm{Cu}^{2+}: \mathrm{A} \beta$ ratios of $0.5: 1,1: 1,1.5: 1$ and 2:1. The results (Figure 2a, Figure S2a) show that presence of $\mathrm{Cu}^{2+}$ inhibits the aggregation of $A \beta(1-42)$ in a dose-dependent manner, resulting in both longer aggregation half-times and reduced maximum levels of ThT emission. We confirmed that the inhibitory effect is specific 
to $\mathrm{Cu}^{2+}$ by demonstrating that another divalent metal ion $\left(\mathrm{Mg}^{2+}\right)$ had no, or a very marginal effect, even when added in 30x molar excess (Figure S3).

a

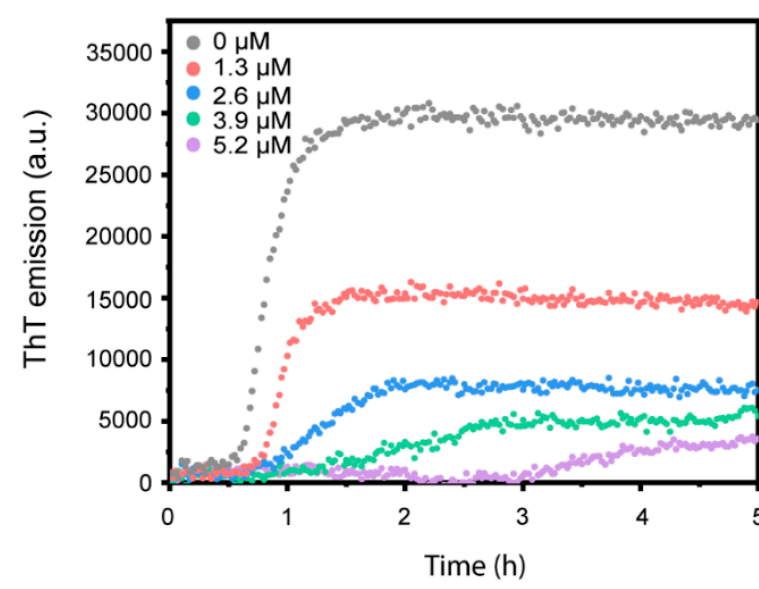

b

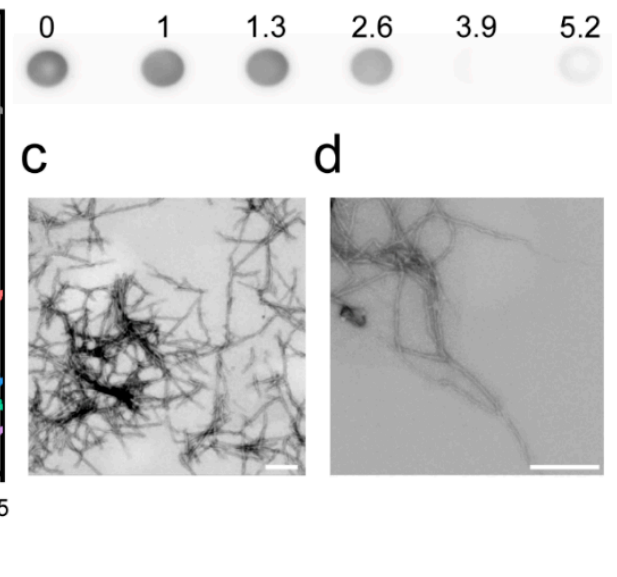

Figure 2. $\mathrm{A} \beta(1-42)$ amyloid formation at $\mathrm{pH} 8.0$ in the presence of $\mathrm{Cu}^{2+}$. (a) Amyloid formation kinetics of $2.6 \mu \mathrm{M} \mathrm{A} \beta(1-42)$ measured by thioflavin-T (ThT) $(5 \mu \mathrm{M})$ fluorescence in the presence of indicated concentrations of $\mathrm{CuCl}_{2}$. Data are shown as representative curves; the full set of replicates $(n=3)$ are shown in Figure S2a. (b) Dot blot showing LOC-positive A $\beta(1-42)$ species at the endpoint of the kinetic experiments shown in (a). The full, uncropped image of the dot-blot membrane is shown in Figure S4. (c,d) TEM images of $2.6 \mu \mathrm{M}$ A $\beta(1-42)$ amyloid fibrils formed in the presence of (c) $1.3 \mu \mathrm{M}$ and (d) $5.2 \mu \mathrm{M} \mathrm{Cu}^{2+}$. The scale bars represent $200 \mathrm{~nm}$.

Using the conformation-sensitive anti-amyloid fibril antibody LOC [86] to detect fibrils, the dot-blot analysis reveals that the fibril yield decreases with increasing $\mathrm{Cu}^{2+}$ concentration (Figure 2b, Figure S4). A densiometric analysis suggests a $\sim 90 \%$ reduction in fibrils at the highest $\mathrm{Cu}^{2+}$ concentration (Figure S5a). This confirms that the decrease in ThT intensity reflects inhibition and is not merely an effect of $\mathrm{Cu}^{2+}$-mediated fluorescence quenching [89]. Control experiments showed, however, that some Cu-mediated quenching also occurs; $34 \%$ of the ThT emission in a sample with pre-formed $\mathrm{A} \beta(1-42)$ fibrils was lost at an $\mathrm{Cu}^{2+}: \mathrm{A} \beta$ ratio of $1: 1$, but the effect was reversible upon the addition of EDTA (Figure S6). This is consistent with the result that the ThT emission at a 1:1 ratio decreased more than expected from the reduction in the LOC-detected fibril yield (Figure S5a).

Our findings are in good qualitative agreement with several other biophysical studies [44,47-50], and thus add to the growing consensus that $\mathrm{Cu}^{2+}$ ions inhibit $\mathrm{A} \beta(1-42)$ aggregation. Whilst a few studies report that $\mathrm{Cu}^{2+}$ ions induce the formation of amorphous aggregates of $A \beta(1-42)[48,90]$, the TEM analysis revealed the formation of mature amyloid fibrils at both sub- and super-stoichiometric $\mathrm{Cu}^{2+}$ concentrations (Figure 2c,d) in our case.

\section{2. $\mathrm{pH}$ and Salt Dependence of the $\mathrm{Cu}^{2+}$-Mediated Inhibition of $\mathrm{A} \beta(1-42)$ Amyloid Formation}

Next, we explored the effect of $\mathrm{Cu}^{2+}$ on $\mathrm{A} \beta(1-42)$ aggregation at different $\mathrm{pHs}$ to mimic the biological conditions that prevail in the endolysosomal pathway, where early accumulation of $A \beta$ aggregates may occur [9]. By successively reducing the $\mathrm{pH}$ from 8.0 to 5.0, we also explored the effect of protonation of $\mathrm{Cu}$-coordinating histidines $\left(\mathrm{pK}_{\mathrm{a}} \sim 6\right)$ in the $\mathrm{A} \beta(1-42) \mathrm{N}$-terminus. To cover this $\mathrm{pH}$ range, a citrate-phosphate buffer was used, which required an increase in the ionic strength to $200 \mathrm{mM}$ compared to the data presented in Figure 2 in order to obtain sufficient buffering capacity at $\mathrm{pH}$ 5.0. This in itself decreased the half-time of $\mathrm{A} \beta(1-42)$ aggregation from $0.82 \pm 0.03 \mathrm{~h}(20 \mathrm{mM})$ to $0.20 \pm 0.01 \mathrm{~h}(200 \mathrm{mM})$ (Figure 3a), consistent with previous observations of salt effects [91,92] and a recent study demonstrating that increased electrostatic screening enhances several mechanistic steps in the self-assembly of $A \beta(1-42)$ [93]. We found that $\mathrm{Cu}^{2+}$ slows down $\mathrm{A} \beta(1-42)$ aggregation also in 
$200 \mathrm{mM}$ salt, pH 8.0, (Figure 3b), but the effect is weaker (1.4 times increase in the half-time at $5.2 \mu \mathrm{M}$ of $\mathrm{Cu}^{2+}$ (Figure 3c) compared to a 4.6 times increase at $20 \mathrm{mM}$ of salt (Figure $2 \mathrm{a}$ )). This suggests that the catalyzing effects of electrostatic screening on $A \beta(1-42)$ aggregation may to some extent outcompete $\mathrm{Cu}^{2+}$-mediated inhibitory actions.

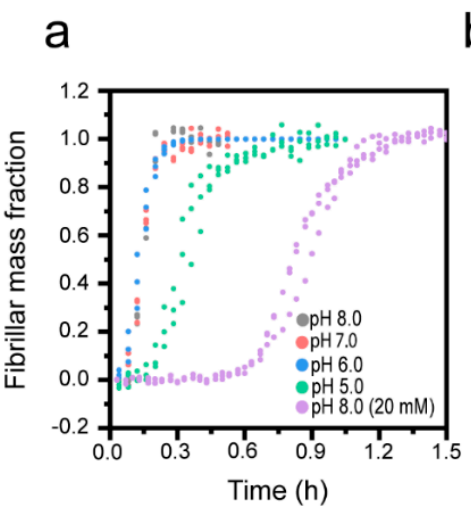

b

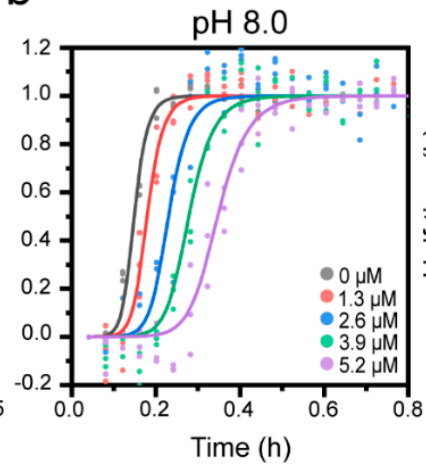

e

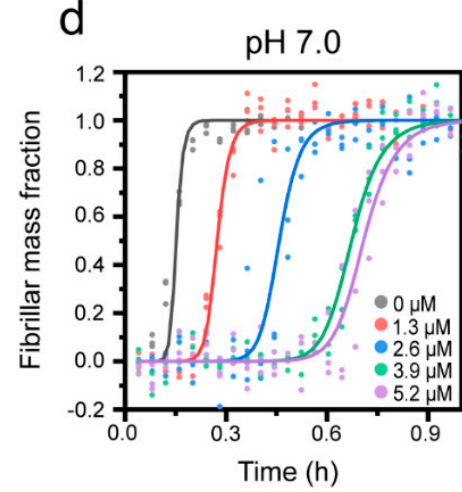

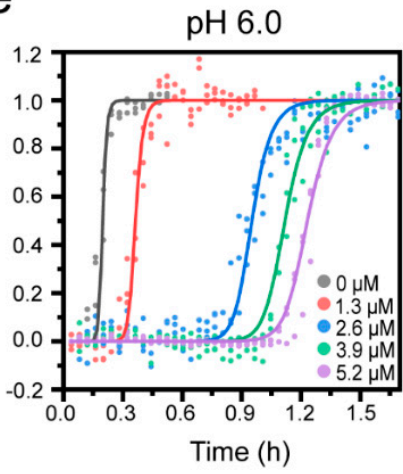

C

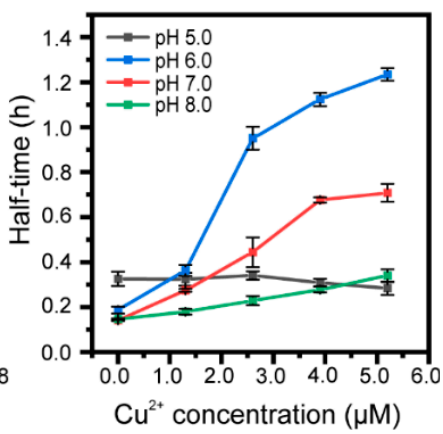

f

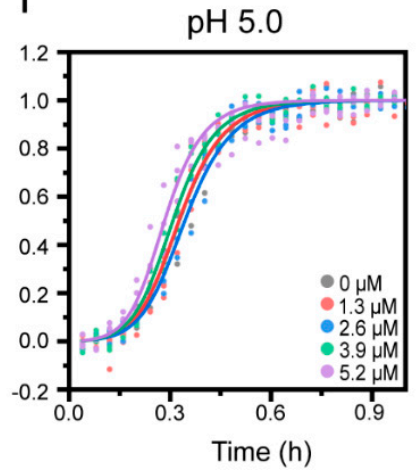

Figure 3. $\mathrm{Cu}^{2+}$ inhibition of $\mathrm{A} \beta(1-42)$ amyloid formation at different $\mathrm{pHs}$. (a) Normalized kinetic profiles of $2.6 \mu \mathrm{M} \mathrm{A} \beta(1-42)$ at various pHs. (b) Normalized kinetic profiles of $2.6 \mu \mathrm{M} A \beta(1-42)$ in a $200 \mathrm{mM}$ sodium phosphate buffer, $\mathrm{pH} \mathrm{8.0,} \mathrm{and} \mathrm{in} \mathrm{the} \mathrm{presence} \mathrm{of} \mathrm{Cu}^{2+}$. (c) Half-times of the aggregation of $2.6 \mu \mathrm{M} \mathrm{A} \beta(1-42)$ at various $\mathrm{pHs}$ in the presence of increasing concentrations of $\mathrm{Cu}^{2+}$. (d-f) Normalized kinetic profiles of $2.6 \mu \mathrm{M} \mathrm{A} \beta(1-42)$ in the presence of increasing concentrations of $\mathrm{Cu}^{2+}$, recorded in $200 \mathrm{mM}$ citrate-phosphate buffers adjusted to (d) $\mathrm{pH}$ 7.0, (e) $\mathrm{pH}$ 6.0, and (f) $\mathrm{pH}$ 5.0.

The effects of $\mathrm{pH}$ on the intrinsic aggregation kinetics of $\mathrm{A} \beta(1-42)$ are shown in Figure 3a, revealing no or very modest changes above $\mathrm{A} \beta(1-42)$ 's isoelectric point $(\mathrm{pI}=5.3,[94])$, whereas at $\mathrm{pH} 5.0$ the aggregation rate increases, which is also reflected by the change in the aggregation halftimes $(0.32 \pm 0.05 \mathrm{~h}$ in $\mathrm{pH} 5.0$, compared to $0.2 \pm 0.01 \mathrm{~h}$ at $\mathrm{pH} 8.0)$ (Figure $3 \mathrm{c})$. Upon lowering the $\mathrm{pH}$ from 8.0 (Figure $3 \mathrm{~b}$ ) to 7.0 or 6.0 (Figure $3 \mathrm{~d}, \mathrm{e}$ ), we observed that the $\mathrm{Cu}^{2+}$-mediated inhibition became increasingly potent; the aggregation curves display extended lag phases and significantly increased half-times (Figure 3c), particularly at $\mathrm{Cu}^{2+}: \mathrm{A} \beta$ ratios equal to or exceeding 1:1. This behavior could relate to differences in the coordination mode and binding stoichiometry of the $\mathrm{Cu}^{2+}: \mathrm{A} \beta$ complex, which has been shown to be $\mathrm{pH}$-dependent in several studies $[64,66,68,69]$. Particularly, the binding of a second $\mathrm{Cu}^{2+}$ ion appears more prominent in mildly acidic ( $\mathrm{pH}$ 6.6) conditions [70], which could explain the sudden increase in the degree of inhibition of aggregation that we observe at a $\mathrm{Cu}^{2+}: \mathrm{A} \beta$ ratio of 1:1 and above at $\mathrm{pH} 7.0$ and 6.0, but not at $\mathrm{pH}$ 8.0. The lack of effect of $\mathrm{Cu}^{2+}$ additions at $\mathrm{pH} 5.0$ (Figure 3f) is most likely due to a loss of binding, related to the full protonation of His residues [67], even if one report suggests a weak $\mathrm{Cu}^{2+}$ binding to $\mathrm{A} \beta$ monomers at this $\mathrm{pH}$ [66]. This result further implies that $A \beta(1-42)$ may release $\mathrm{Cu}^{2+}$ during endolysosomal acidification following endocytic 
uptake [95], and that this in turn could lead to both aggravated aggregation of $\mathrm{A} \beta$ and putative toxicity due to free $\mathrm{Cu}^{2+}$ ions.

\section{3. $\mathrm{Cu}^{2+}$-Mediated Inhibition of A $\beta(1-42)$ Aggregation Affects the Fibril Elongation Step}

It has been shown in several independent studies that the rate-limiting step in unseeded aggregation of $A \beta(1-42)$ is secondary nucleation [14,18,51]. Aggregation modulators can, however, act on different mechanistic steps [96]. To investigate how $\mathrm{Cu}^{2+}$ affects the mechanism of $\mathrm{A} \beta(1-42)$ aggregation, we returned to $\mathrm{pH} 8.0$ and low ionic strength conditions and explored how the aggregation kinetics of $\mathrm{A} \beta(1-42)$ were affected by the addition of pre-formed fibril seeds (prepared in the absence of $\mathrm{Cu}^{2+}$ ). Figure $4 \mathrm{a}$ shows the kinetic profiles of $2.6 \mu \mathrm{M} \mathrm{A} \beta(1-42)$ with increasing $\mathrm{Cu}^{2+}$ and no added seeds (the normalized data from Figure S2a). Figure $4 b, c$ shows the same experiment in the presence of $5 \mathrm{~mol} \%$ or $25 \mathrm{~mol} \% \mathrm{~A} \beta(1-42)$ fibril seeds (mol\% on a monomer basis). It is clear that even at strongly seeded conditions (25\%), the aggregation of $A \beta(1-42)$ is reduced in a dose-dependent manner by $\mathrm{Cu}^{2+}$. This is further visualized by the half-time dependence on the $\mathrm{Cu}^{2+}$ concentration, as shown in Figure $4 \mathrm{~d}$ and Figure S7. The distinct concentration-dependent increase in half-time with 5\% and $25 \%$ seeds strongly suggests that $\mathrm{Cu}^{2+}$-mediated inhibition is not due to a reduction in the primary nucleation rate, since the addition of seeds bypasses this reaction step [97]. Instead, the retardation of $A \beta(1-42)$ aggregation by $\mathrm{Cu}^{2+}$ appears to be associated with inhibition of secondary processes and/or elongation. It has been shown that elongation can be distinguished from secondary nucleation at strongly seeded conditions where fibril elongation dominates over all nucleation processes [17].
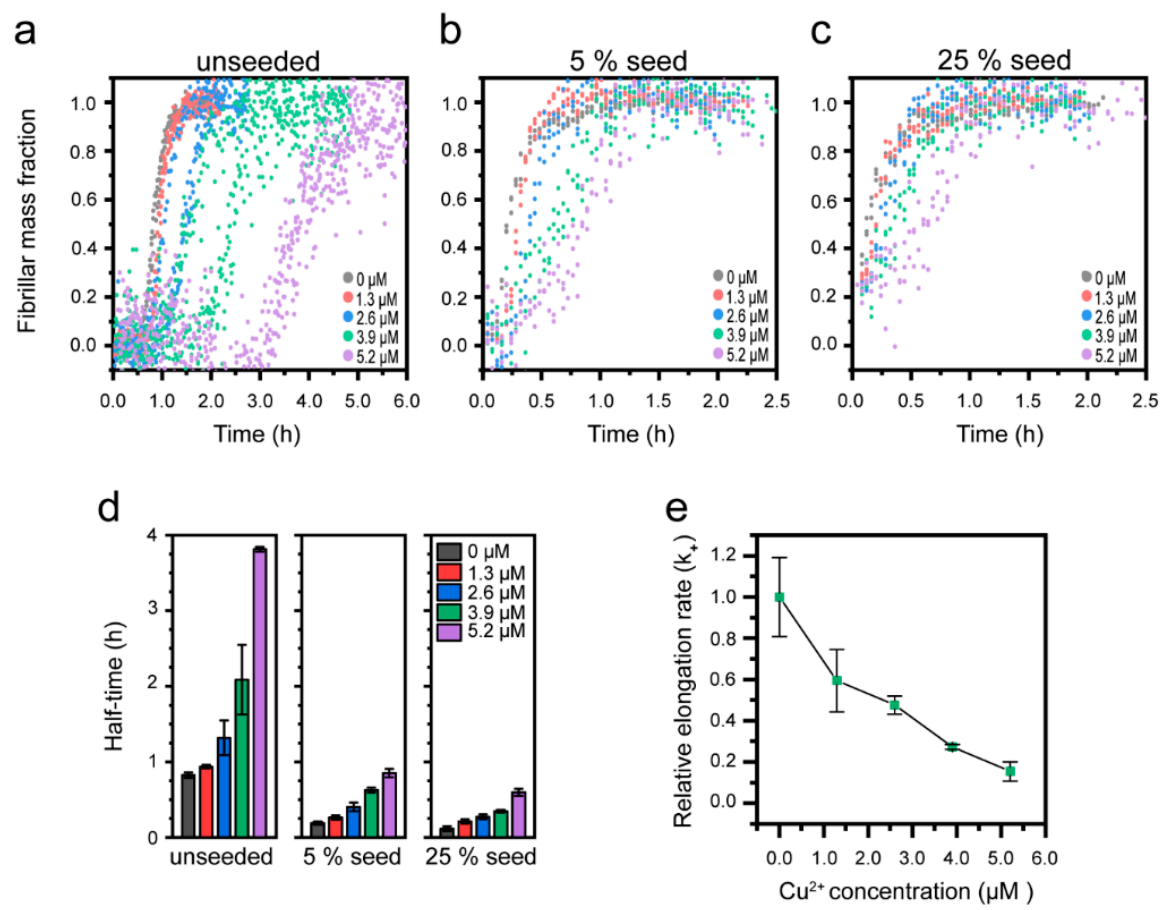

Figure 4. Effect of $\mathrm{Cu}^{2+}$ on seeded $\mathrm{A} \beta(1-42)$ amyloid formation at $\mathrm{pH} 8.0$ (a-c) Normalized kinetic profiles of $2.6 \mu \mathrm{M} \mathrm{A} \beta(1-42)$ in presence of indicated concentrations of $\mathrm{Cu}^{2+}$ in reactions with (a) no seeds, (b) $5 \%$ seeds, and (c) $25 \%$ seeds. (d) Half-times of $A \beta(1-42)$ aggregation, extracted from the data in $(\mathbf{a}-\mathbf{c})$. Error bars represent the standard deviation $(n=3)$. (e) Relative elongation rate of 2.6 $\mu \mathrm{M} \mathrm{A} \beta(1-42)$ in presence of $25 \%$ seeds as a function of $\mathrm{Cu}^{2+}$ concentration, as estimated using a linear approximation of the kinetic slope up until a fibril mass fraction of 0.5 . All the rate constants are relative to that of $2.6 \mu \mathrm{M}$ of $\mathrm{A} \beta(1-42)$ in absence of $\mathrm{Cu}^{2+}$.

Since our data show that a significant effect of $\mathrm{Cu}^{2+}$ on the aggregation half-times remains with $25 \%$ seeds, we proceeded to estimate the elongation rates by fitting a linear curve to the initial growth 
phase (up to $50 \%$ fibril mass fraction) under strongly (25\%) seeded conditions (Figure S8a), as described by Abelein et al. [51]. This analysis revealed a $\mathrm{Cu}^{2+}$ concentration-dependent decrease in the relative elongation rate (Figure 4e), supporting the notion that $\mathrm{Cu}^{2+}$ inhibition acts on fibril elongation. Similar observations have been made in studies on the effect of $\mathrm{Zn}^{2+}$ on the aggregation of $\mathrm{A} \beta(1-40)$ [51].

To quantitatively determine the elongation rate constants together with the rates for other steps in the reaction, we performed a global fitting to the combined data sets of unseeded and seeded ThT emission kinetics in the Amylofit web interface, using a secondary nucleation model for seeded amyloid growth [85]. This allowed us to independently determine the microscopic rate constants for primary nucleation $\left(k_{n}\right)$, elongation $\left(k_{+}\right)$, and secondary nucleation $\left(k_{2}\right)$. The elongation rate constant $\left(\mathrm{k}_{+}\right)$was probed as a fitting parameter, (allowed to vary with the $\mathrm{Cu}^{2+}$ concentration, but kept constant across seeding concentrations), and the two other rate constants were fitted as fixed global parameters. The resulting fits are shown in Figure $5 \mathrm{a}-\mathrm{c}$, and the associated rate constants are given in Table 1 . We repeated the analysis with, respectively, $\mathrm{k}_{\mathrm{n}}$ and $\mathrm{k}_{2}$ as fitting parameters (Figure S9), further substantiating that $\mathrm{Cu}^{2+}$ cannot inhibit the primary nucleation step of the $\mathrm{A} \beta(1-42)$ aggregation reaction (Figure $S 9 a-c)$.
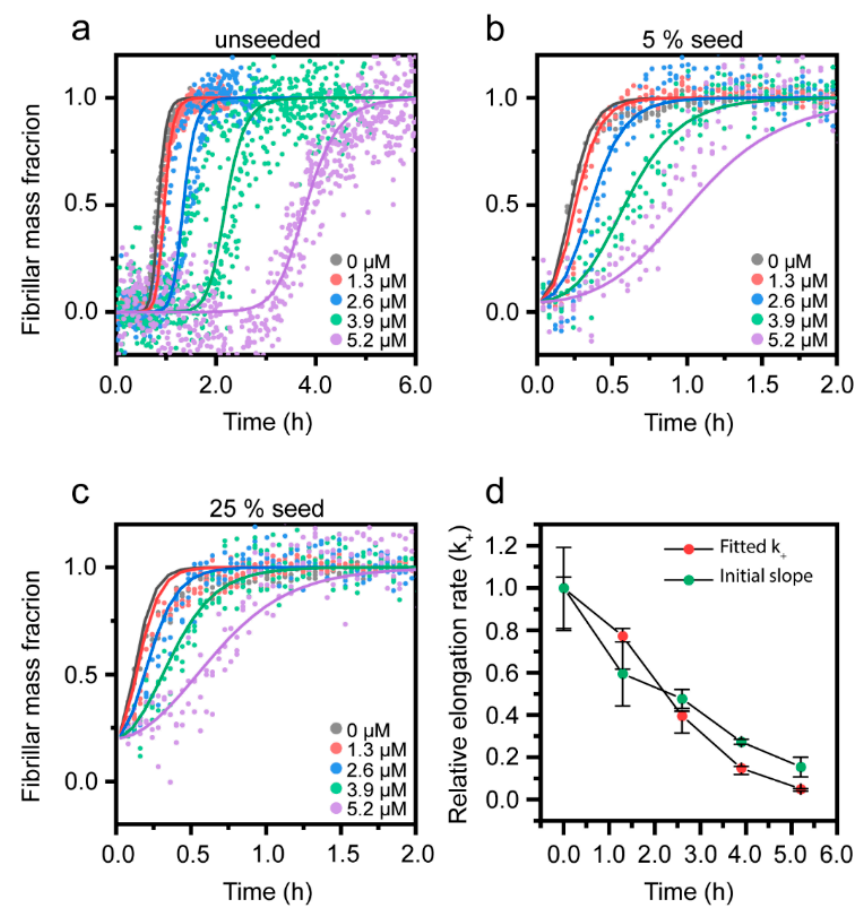

d

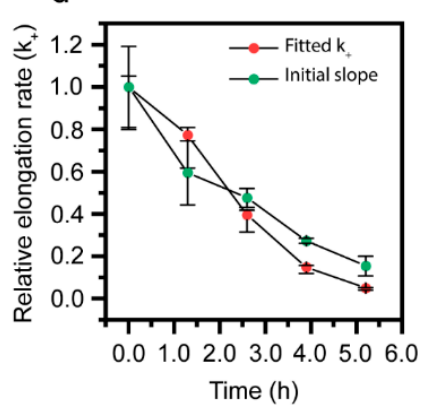

Figure 5. Fitting of the $\mathrm{A} \beta(1-42)$ aggregation kinetics in the presence of $\mathrm{Cu}^{2+}$ at $\mathrm{pH} 8.0$ to mathematical models of amyloid formation. (a-c) Normalized kinetic profiles of $2.6 \mu \mathrm{M} \mathrm{A} \beta(1-42)$ at $\mathrm{pH} 8.0$ corresponding to the data in Figure 4. Solid lines are the global fits to data using a model for $\mathrm{Cu}^{2+}$-dependent variation in the elongation rate constant $\left(\mathrm{k}_{+}\right)$. (d) Relative change in the elongation rate constant $\left(k_{+}\right)$determined from the fitting of the data in $(\mathbf{a}-\mathbf{c})$ compared to the relative rate determined via the linear approximation of the initial slope at $25 \%$ seeds in Figure $4 \mathrm{e}$. All the rate constants are relative to that of $2.6 \mu \mathrm{M}$ of $\mathrm{A} \beta(1-42)$ in the absence of $\mathrm{Cu}^{2+}$.

From a mathematical perspective, it is more difficult to distinguish between the fits for secondary nucleation inhibition $\left(\mathrm{k}_{2}\right.$, Figure S9d-f) and elongation inhibition $\left(\mathrm{k}_{+}\right.$, Figure $\left.5 \mathrm{a}-\mathrm{c}\right)$, but the latter (which also has a slightly better goodness of fit, 0.0206 vs 0.0214 ; the corresponding parameter for the rejected $\mathrm{k}_{\mathrm{n}}$ fit was 0.0265 ) captures better the initial lagging behavior at high $\mathrm{Cu}^{2+}$ ratios. Furthermore, increasing the $\mathrm{Cu}^{2+}$ concentration results in longer lag times together with successively decreased steepness of the slopes of the aggregation kinetic curves (Figure 4a), which is expected for elongation inhibitors [16]. The change in the elongation rate constant $\left(\mathrm{k}_{+}\right)$with increasing $\mathrm{Cu}^{2+}$ concentration determined from the fitting (Figure 5e, Table 1) overlaps very well with the relative elongation rate 
constants estimated using the initial slope of the kinetic profiles (Figure 4e). We therefore conclude that $\mathrm{Cu}^{2+}$ inhibits the $\mathrm{A} \beta(1-42)$ aggregation by interfering with the fibril elongation step. In order to compare the fitted rate constants for the $\mathrm{A} \beta(1-42)$ aggregation in the absence of $\mathrm{Cu}^{2+}$ with previously published values, we calculated the combined rate constants $k_{n} k_{+}$and $k_{2} k_{+}$from the data given in Table 1. This yielded $2.5 \times 10^{7} \mathrm{M}^{-2} \mathrm{~h}^{-2}$ and $8.6 \times 10^{18} \mathrm{M}^{-3} \mathrm{~h}^{-2}$ for $\mathrm{k}_{\mathrm{n}} \mathrm{k}_{+}$and $\mathrm{k}_{2} \mathrm{k}_{+}$, in good agreement with previous reports [14,51], demonstrating the robustness of this $\mathrm{A} \beta(1-42)$ aggregation system.

Table 1. Rate constants for $A \beta(1-42)$ aggregation in the presence of $\mathrm{Cu}^{2+}$. Rate constants were determined by fitting the seeded kinetic data with $k_{+}$as a dependent variable and $k_{n}$ and $k_{2}$ as globally fitted fixed parameters (e.g., elongation inhibition). The fitted values for $k_{n}$ and $k_{2}$ were $1.2 \times 10_{-9.2 \times 10^{-3}}^{-1.9 \times 1 \mathrm{M}^{-2}} \mathrm{~h}^{-1}$ and $4.1 \times 10_{-3.5 \times 10^{9}}^{10^{+6.7 \times 10^{9}}} \mathrm{M}^{-2} \mathrm{~h}^{-1}$ respectively. The upper/lower errors define the interval in which the rate constant variation does not significantly changing the goodness of fit [85].

\begin{tabular}{|c|c|c|}
\hline$\left[\mathrm{Cu}^{2+}\right]$ & $\mathbf{k}_{+}$ & Upper/Lower Error \\
\hline$(\mu \mathrm{M})$ & $\left(M^{-1} h^{-1}\right)$ & $\left(M^{-1} h^{-1}\right)$ \\
\hline 0 & $2.1 \times 10^{8}$ & $\begin{array}{l}+1.1 \times 10^{7} \\
-4.2 \times 10^{7}\end{array}$ \\
\hline 1.3 & $1.6 \times 10^{6}$ & $\begin{array}{l}+7.5 \times 10^{6} \\
-3.2 \times 10^{7}\end{array}$ \\
\hline 2.6 & $8.2 \times 10^{7}$ & $\begin{array}{l}+4.5 \times 10^{6} \\
-1.7 \times 10^{7}\end{array}$ \\
\hline 3.9 & $3.1 \times 10^{7}$ & $\begin{array}{l}+1.6 \times 10^{6} \\
-6.2 \times 10^{6}\end{array}$ \\
\hline 5.2 & $1.0 \times 10^{7}$ & $\begin{array}{l}+5.3 \times 10^{5} \\
-2.1 \times 10^{6}\end{array}$ \\
\hline
\end{tabular}

Our results show that $\mathrm{Cu}^{2+}$ reduces the elongation rate of $\mathrm{A} \beta(1-42)$ by $60 \%$ at a $1: 1 \mathrm{Cu}^{2+}: \mathrm{A} \beta$ ratio and by $95 \%$ at a 2:1 ratio. These values can be compared to the elongation inhibitory effect of $\mathrm{Zn}^{2+}$ on $\mathrm{A} \beta(1-40)$, which resulted in an $80 \%$ reduction in the rate constant at sub-stoichiometric concentrations (2.5:20 molar ratio) [51] and to the extracellular chaperone clusterin, which elicits the strong inhibition of elongation even at molar ratios as low as 1:100 [80]. In comparison, the $\mathrm{Cu}^{2+-}$ mediated inhibition appears to be weaker.

Fibril elongation occurs via monomer addition to the growing fibril end, and the inhibition could therefore be envisioned to result from $\mathrm{Cu}^{2+}$ binding to the attaching monomer, the growing fibril, or both, especially since $\mathrm{Cu}^{2+}$ has been reported to bind both $\mathrm{A} \beta(1-42)$ monomers and fibrils with a comparable affinity [63]. Most studies suggest that elongation occurs via templating interactions, where the misfolding rearrangement is aided by monomer contacts to the fibril end [98-100]. Molecular dynamics simulations have suggested that it is the $\mathrm{N}$-terminal part of the $\mathrm{A} \beta$ peptide that forms the initial contact with the growing fibril end [101]. It can therefore be envisioned that the $\mathrm{Cu}^{2+}$ interaction, promoting loop-formation in the N-terminus of either the free $A \beta(1-42)$ monomer or the $A \beta(1-42)$ entities at the fibril end (Figure 1a), imposes conformational restrictions or charge repulsions that impede monomers from attaching to the fibril ends.

\subsection{Effect of $\mathrm{Cu} u^{+}$on $\mathrm{A} \beta(1-42)$ Aggregation}

Since copper can exist in, and cycle between, two redox states $\left(\mathrm{Cu}^{+}\right.$and $\left.\mathrm{Cu}^{2+}\right)$, we also studied the effect of $\mathrm{Cu}^{+}$on the aggregation kinetics of $\mathrm{A} \beta$ peptides. Notably, this has not been explored previously, in part because $\mathrm{Cu}^{+}$is difficult to work with in aired solutions. To create and keep $\mathrm{Cu}^{+}$in solution, we used the reducing agent dithiothreitol (DTT), in similarity to work with $\mathrm{Cu}^{+}$chaperones [82]. The aggregation of $\mathrm{A} \beta(1-42)$ in presence of $\mathrm{CuCl}_{2}$ and a $5 x$ molar excess of DTT to $\mathrm{Cu}$ (creating $\mathrm{Cu}^{+}$) resulted in a modest but reproducible concentration-dependent increase in the aggregation rate of 
$A \beta(1-42)$ (Figure 6a) (for two additional replicates of the experiments, see supporting Figure S10), thus opposite to the effect of $\mathrm{Cu}^{2+}$. Control experiments showed that DTT on its own had no effect (Figure S11). The kinetic results were confirmed by dot blot (Figure 6b, Figure S4), showing no decrease in the fibril yield in the presence of $\mathrm{Cu}^{+}$. TEM imaging revealed the presence of typical amyloid fibril aggregates at both sub- and super stochiometric $\mathrm{Cu}^{+}: \mathrm{A} \beta$ ratios (Figure $6 c, d$ ), similar to those observed with $\mathrm{Cu}^{2+}$, suggesting that copper ions and redox state have no major effect on the morphology of formed amyloid fibrils.

a

b

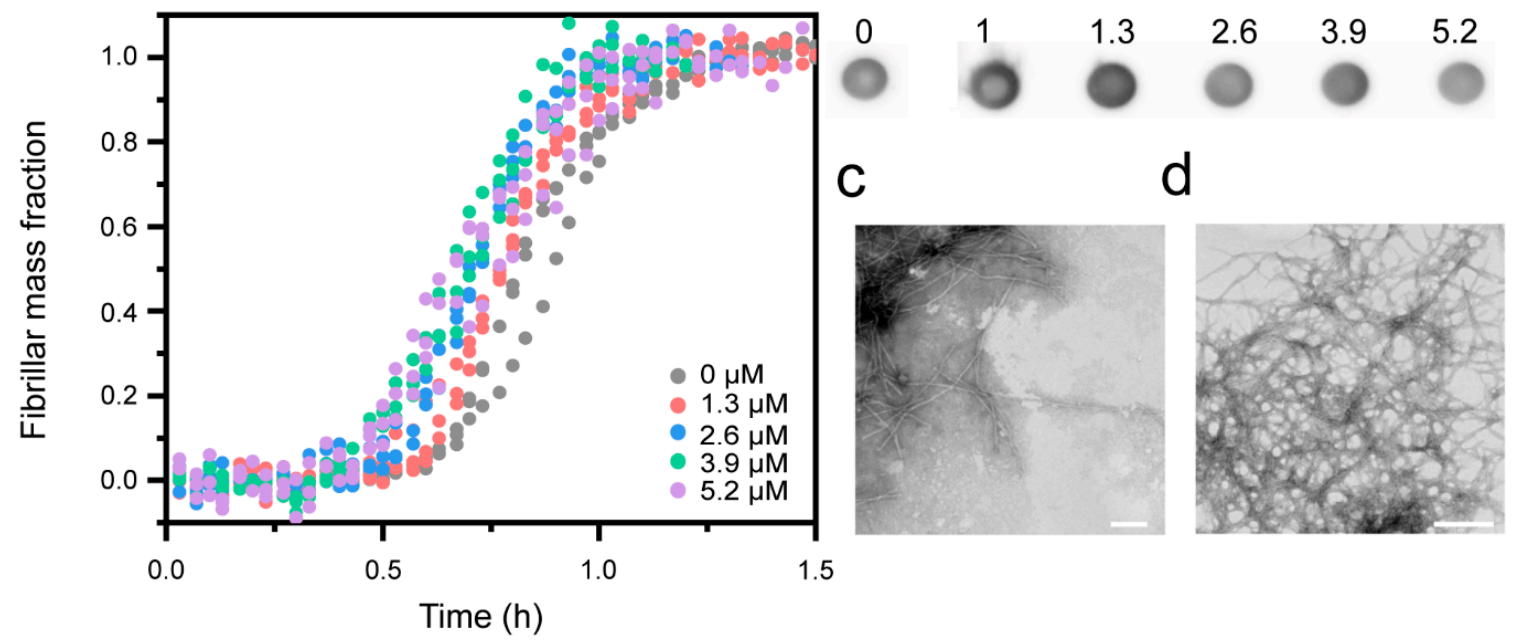

Figure 6. $\mathrm{A} \beta(1-42)$ amyloid formation in the presence of $\mathrm{Cu}^{+}$at $\mathrm{pH}$ 8.0. (a) Normalized kinetic profiles of $2.6 \mu \mathrm{M} A \beta(1-42)$, measured by ThT $(5 \mu \mathrm{M})$ fluorescence, in the presence of indicated concentrations of $\mathrm{CuCl}_{2}$ and $5 \mathrm{x}$ molar excess 1,4-dithiothreitol (DTT) to generate $\mathrm{Cu}^{+}$. The non-normalized dataset is shown in Figure S2b. (b) Dot blot showing LOC-positive A $\beta(1-42)$ species at the endpoint of the kinetic experiments shown in (a). The full, uncropped image of the dot-blot membrane is shown in Figure S4. (c,d) TEM images of $2.6 \mu \mathrm{M}$ A $\beta(1-42)$ amyloid fibrils formed in the presence of (c) $1.3 \mu \mathrm{M}$ and (d) $5.2 \mu \mathrm{M} \mathrm{Cu}^{2+}$. The scale bars represent $200 \mathrm{~nm}$.

\section{5. $C u^{+}$Enhances $A \beta(1-42)$ Aggregation by Catalysis of Primary Nucleation}

$\mathrm{Cu}^{+}$has been reported to bind $\mathrm{A} \beta(1-42)$ via bidentate coordination to imidazoles of His13 and His14, located adjacent to the $\mathrm{N}$-terminal side of the first $\beta$-sheet in the fibril core, but His6 may also be involved (Figure 1d, [65]). In order to rationalize how this leads to the enhancement of $A \beta(1-42)$ aggregation, we performed seeded experiments analogous to those explained in Section 3.3.

We find that whilst $\mathrm{Cu}^{+}$shortens the half-time of unseeded $\mathrm{A} \beta(1-42)$ aggregation from $0.84 \pm 0.06$ to $0.69 \pm 0.07$ (Figure 7a,d), there is no significant effect of $\mathrm{Cu}^{+}$on seeded reactions (Figure $7 \mathrm{~b}-\mathrm{d}$ ), suggesting that secondary pathways are not affected. Consistently, $\mathrm{Cu}^{+}$had no effect on the initial slope of the kinetic traces under strongly seeded (25\%) conditions, and therefore not on the relative elongation rate constants (Figure 7e and Figure S7b). Furthermore, the observed characteristic shortening of the lag time, without apparent alterations to the steepness of the slope of the aggregation curves [97], strongly supports that the $\mathrm{Cu}^{+}$-mediated catalysis of the $\mathrm{A} \beta$ aggregation acts on primary nucleation. Although in aired solutions, $\mathrm{Cu}^{+}$will over time oxidize to $\mathrm{Cu}^{2+}$, it has been previously shown that under reducing conditions (1-fold excess ascorbate) $\mathrm{Cu}^{+}$remains stable for at least $1.5 \mathrm{~h} \mathrm{[65],} \mathrm{which} \mathrm{is}$ longer than the experimental time span in Figure 6a. 
a

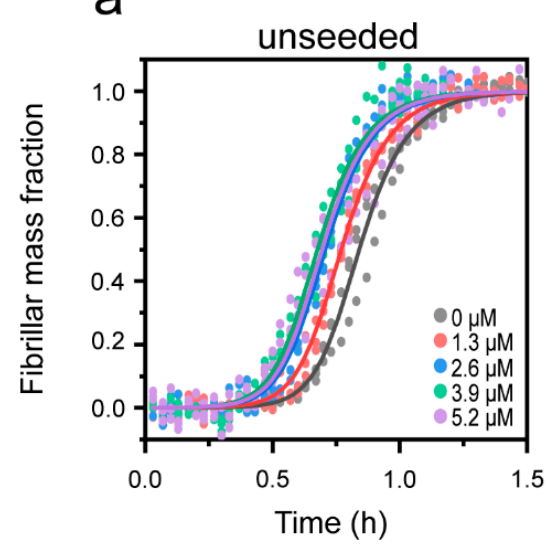

d

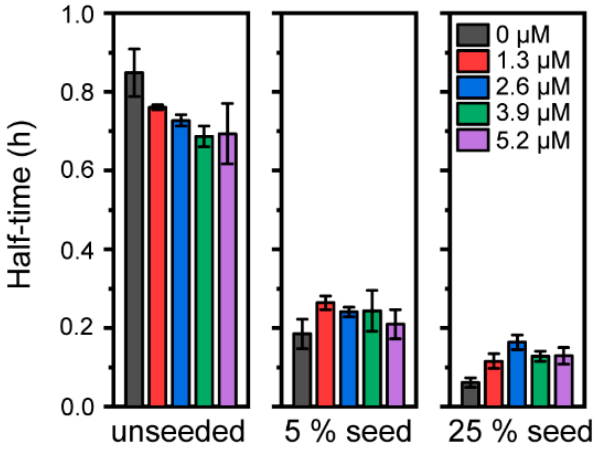

b

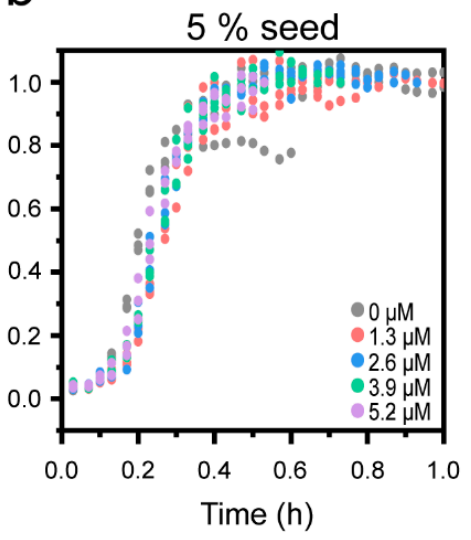

C

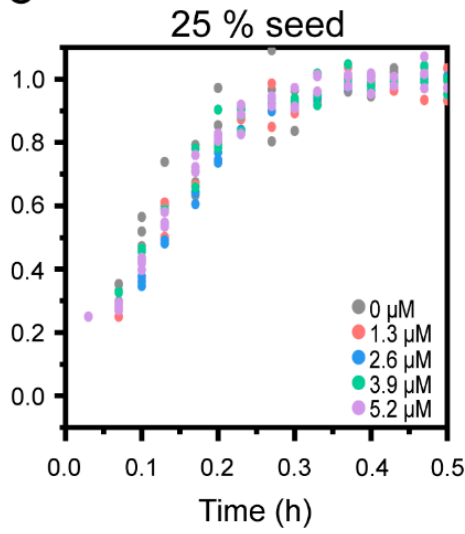

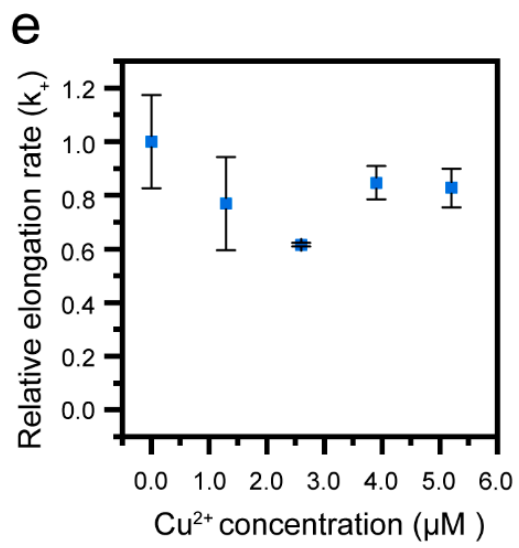

Figure 7. Effect of $\mathrm{Cu}^{+}$on seeded $\mathrm{A} \beta(1-42)$ amyloid formation at $\mathrm{pH}$ 8.0. (a-c) Normalized kinetic profiles of $2.6 \mu \mathrm{M} \mathrm{A} \beta(1-42)$ in presence of indicated concentrations of $\mathrm{Cu}^{2+}$ in reactions with (a) no seeds, (b) $5 \%$ seeds, and (c) $25 \%$ seeds. (d) Half-times of A $\beta(1-42)$ aggregation extracted from the data in $(\mathbf{a}-\mathbf{c})$. Error bars represent the standard deviation $(\mathrm{n}=3)$. (e) Relative elongation rate of $2.6 \mu \mathrm{M}$ $\mathrm{A} \beta(1-42)$ in the presence of $25 \%$ seeds as a function of $\mathrm{Cu}^{2+}$ concentration, as estimated using a linear approximation of the kinetic slope up until a fibril mass fraction of 0.5 . All the rate constants are relative to that of $2.6 \mu \mathrm{M} \mathrm{A} \beta(1-42)$ in the absence of $\mathrm{Cu}^{2+}$. The solid lines in (a) are the global fits to data using a model for $\mathrm{Cu}^{2+}$-dependent variation in the combined rate constant for primary nucleation and elongation $\left(\mathrm{k}_{\mathrm{n}} \mathrm{k}_{+}\right)$.

We globally fitted the unseeded $A \beta(1-42)$ aggregation data in the presence of $\mathrm{Cu}^{+}$using the Amylofit web interface [85] and a secondary nucleation model for unseeded amyloid growth. The fit (solid lines in Figure 7a) shows that the mild aggregation-enhancing effect of $\mathrm{Cu}^{+}$is well-described by an increase in the combined primary nucleation and elongation rate constant $k_{n} k_{+}$; the resulting combined rate constants from the fitting are shown in Table 2.

There are relatively few studies investigating the $\mathrm{Cu}^{+}-\mathrm{A} \beta$ interaction, but due to the preferred linear coordination geometry involving His13 and His14 [65,102], it is conceivable that $\mathrm{Cu}^{+}$cannot simultaneously bind these two ligands in the fibrillar state (due to steric restrictions imposed by the alternating directions of side-chain residues in or near the cross- $\beta$ core (Figure $1 b$ )). However, it is plausible that $\mathrm{Cu}^{+}$may interact with His13 and His14 residues on different monomers in the amyloid fibrils. Our data would then be consistent with a model in which $\mathrm{Cu}^{+}$catalyzes the formation of $A \beta(1-42)$ dimers, which are the minimal elongation-competent $A \beta(1-42)$ units [14], thus promoting primary nucleation. 
Table 2. Rate constants for $\mathrm{A} \beta(1-42)$ aggregation in presence of $\mathrm{Cu}^{+}$. Rate constants were determined by fitting unseeded kinetic data and setting the combined rate constant $k_{n} k_{+}$as the dependent variable and the combined rate constant $\mathrm{k}_{2} \mathrm{k}_{+}$as a globally fitted fixed parameter (e.g., primary nucleation catalysis). The fitted value for $\mathrm{k}_{+} \mathrm{k}_{2}$ was $4.9 \times 10_{-1.1 \times 10^{17}}^{18^{+6.8116}} \mathrm{M}^{-3} \mathrm{~h}^{-2}$. The upper/lower errors define the interval in which the rate constant variation does not significantly change the goodness of fit [85].

\begin{tabular}{|c|c|c|}
\hline$\left[\mathrm{Cu}^{+}\right]$ & $k_{+} k_{n}$ & Upper/Lower Error \\
\hline$(\mu \mathrm{M})$ & $\left(M^{-2} h^{-2}\right)$ & $\left(M^{-2} h^{-2}\right)$ \\
\hline 0 & $5.5 \times 10^{8}$ & $\begin{array}{l}+5.6 \times 10^{7} \\
-3.9 \times 10^{7}\end{array}$ \\
\hline 1.3 & $1.4 \times 10^{9}$ & $\begin{array}{l}+1.3 \times 10^{8} \\
-1.0 \times 10^{8}\end{array}$ \\
\hline 2.6 & $3.2 \times 10^{9}$ & $\begin{array}{l}+2.6 \times 10^{8} \\
-2.1 \times 10^{8}\end{array}$ \\
\hline 3.9 & $4.7 \times 10^{9}$ & $\begin{array}{l}+4.3 \times 10^{8} \\
-2.8 \times 10^{8}\end{array}$ \\
\hline 5.2 & $3.7 \times 10^{9}$ & $\begin{array}{l}+3.0 \times 10^{8} \\
-2.4 \times 10^{8}\end{array}$ \\
\hline
\end{tabular}

\section{Conclusions}

This study explores the effect of copper ions on $A \beta(1-42)$ amyloid formation in vitro, identifying effects on the overall aggregation rate as well as on discrete mechanistic steps of the aggregation pathway (illustrated in Figure 8). Our results extend the growing body of literature, suggesting that $\mathrm{Cu}^{2+}$, the major extracellular copper form [21], acts in an inhibitory manner on fibril formation [44-50]. We solidify this view by seeding experiments and kinetic analyses, which conclusively show how $\mathrm{Cu}^{2+}$ primarily impedes fibril elongation at both sub- and super-stoichiometric ratios and in a concentration range that is relevant to the conditions that prevail in the brain. The $\mathrm{Cu}^{2+}$-mediated inhibition is modest in comparison to other elongation inhibitors, including $\mathrm{Zn}^{2+}$ (see above and [51]). This is consistent with observations of the significant accumulation of $\mathrm{Cu}^{2+}$ in $\mathrm{AD}$ plaques [21], and suggests that $\mathrm{Cu}^{2+}$ impedes, rather than completely blocks, $A \beta(1-42)$ aggregation. Although the inhibition of $A \beta(1-42)$ aggregation is a tractable goal to limit the onset and progression of $A D$, it is important to recognize that elongation inhibition, under conditions where primary and secondary nucleation proceeds, can instead drive the formation of small fibrils and oligomers [12,16]. It is therefore possible that $\mathrm{Cu}^{2+}$, despite its ability to reduce the amount of mature fibrils formed, as we report here, contributes to $\mathrm{A} \beta$ toxicity in the brain. Furthermore, although we describe a strong stoichiometry-dependent inhibitory effect of $\mathrm{Cu}^{2+}$ at a mildly acidic $\mathrm{pH}$, we also report a loss of function at $\mathrm{pH}$ 5.0, a condition that prevails in late endosomes and lysosomes and which may drive $A \beta$ aggregation in intraneuronal locations of the brain.

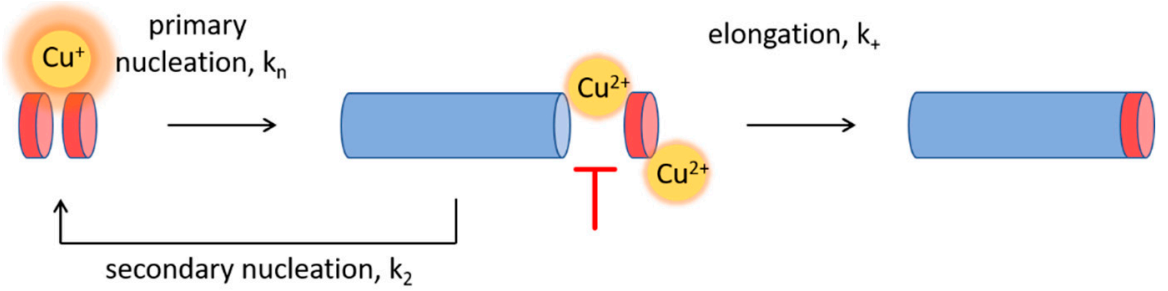

Figure 8. Schematic model showing the differential effects of $\mathrm{Cu}^{2+}$ and $\mathrm{Cu}^{+}$on the amyloid formation of $\mathrm{A} \beta(1-42)$, with $\mathrm{Cu}^{2+}$ acting in an inhibitory manner on elongation and $\mathrm{Cu}^{+}$mildly affecting primary nucleation. 
Furthermore, we demonstrate that the effect of $\mathrm{Cu}$ is dependent on the redox state by including the first experimental evidence that $\mathrm{Cu}^{+}$also has an $\mathrm{A} \beta(1-42)$ aggregation-modulatory effect. Through kinetic analysis and seeded experiments, we report that $\mathrm{Cu}^{+}$accelerates fibril formation by mild catalysis of primary nucleation, possibly related to $\mathrm{Cu}^{+}$-mediated dimer formation. This finding is important, particularly in relation to observations that the redox cycling of $\mathrm{A} \beta$-bound $\mathrm{Cu}$ can contribute to the generation of reactive oxygen species in the brain [32]. Our results suggest that such reactions, which result in $\mathrm{Cu}^{+}$bound to $\mathrm{A} \beta$, may also accelerate aggregation, thereby constituting a dual toxic mechanism. Altogether, our study sheds more light on the possible pathological relevance of $\mathrm{Cu}$ in Alzheimer's disease and suggests a complex pivotal role of $\mathrm{Cu}$ in $\mathrm{A} \beta(1-42)$ aggregation modulation that warrants further investigation in biological in vivo environments. The therapeutic value of $\mathrm{Cu}-\mathrm{A} \beta(1-42)$ interactions should also be taken into account in future strategies to develop disease-modifying treatments.

Supplementary Materials: The following supplementary results are available online at http://www.mdpi. com/2218-273X/10/6/924/s1; Figure S1: Size-exclusion (SEC) purification of A $\beta(1-42)$ monomers; Figure S2: Reproducibility of $A \beta(1-42)$ aggregation kinetics; Figure S3: $\mathrm{A} \beta(1-42)$ amyloid formation in presence of $\mathrm{MgCl}_{2}$; Figure S4: Dot blot; Figure S5: Relative ratio of fibrillar content at different $\mathrm{Cu}$ concentrations; Figure S6: Quenching of ThT by $\mathrm{Cu}^{2+}$; Figure S7: Half-time of $\mathrm{A} \beta(1-42)$ aggregation in presence of $\mathrm{Cu}^{2+}$; Figure S8: Initial slope analysis of $25 \%$ seeded aggregation curves; Figure S9: Fitting of $A \beta(1-42)$ amyloid kinetic data in presence of $\mathrm{Cu}^{2+}$ to models of primary nucleation and secondary nucleation inhibition; Figure S10: Amyloid formation in presence of $\mathrm{Cu}^{+}$- extra data; Figure S11: Dithiotreitol (DTT) has no effect on A $\beta(1-42)$ amyloid formation; Table S1: Buffer specifications.

Author Contributions: Conceptualization, N.S. and E.K.E.; Formal analysis, N.S., D.B. and E.K.E.; Funding acquisition, E.K.E.; Investigation, N.S., D.B. and I.H.; Methodology, N.S., D.B., I.H., P.W.-S. and E.K.E.; Resources, E.K.E.; Visualization, N.S., D.B. and E.K.E.; Writing—original draft, N.S., D.B., P.W.-S. and E.K.E.; Writing一review and editing, N.S., D.B., I.H., P.W.-S. and E.K.E. All authors have read and agreed to the published version of the manuscript.

Funding: This research was funded by grants to E.K.E from the Swedish Research Council (grant number 2016-03902) and Chalmers Excellence Initiative Nano". N.S is an Excellence PhD student funded by Chalmers Nano program. P.W.S. acknowledges funding from the Wallenberg Scholar Program and the Swedish Research Council (grant number 2019-03673).

Acknowledgments: We thank Henrik Biverstål at the Karolinska Institute for help with the setup of the recombinant $\mathrm{A} \beta(1-42)$ production and the gift of the $\mathrm{A} \beta(1-42)$-encoding plasmid. Emma Lorentzon is acknowledged for help with TEM image acquisition. These images were recorded using instruments and technical support from the Centre for Cellular Imaging (CCI) core facility at Gothenburg University.

Conflicts of Interest: The authors declare no conflict of interest.

\section{References}

1. Masters, C.L.; Simms, G.; Weinman, N.A.; Multhaup, G.; McDonald, B.L.; Beyreuther, K. Amyloid plaque core protein in Alzheimer disease and Down syndrome. Proc. Natl. Acad. Sci. USA 1985, 82, 4245-4249. [CrossRef] [PubMed]

2. Hebert, L.E.; Weuve, J.; Scherr, P.A.; Evans, D.A. Alzheimer disease in the United States (2010-2050) estimated using the 2010 census. Neurology 2013, 80, 1778-1783. [CrossRef] [PubMed]

3. Prince, M.J. World Alzheimer Report 2015: The Global Impact of Dementia: An Analysis of Prevalence, Incidence, Cost and Trends; Alzheimer's Disease International: London, UK, 2015.

4. Glenner, G.G.; Wong, C.W. Alzheimer's disease: Initial report of the purification and characterization of a novel cerebrovascular amyloid protein. Biochem. Biophys. Res. Commun. 1984, 120, 885-890. [CrossRef]

5. Hardy, J.; Allsop, D. Amyloid deposition as the central event in the aetiology of Alzheimer's disease. Trends Pharmacol. Sci. 1991, 12, 383-388. [CrossRef]

6. LaFerla, F.M.; Green, K.N.; Oddo, S. Intracellular amyloid- $\beta$ in Alzheimer's disease. Nat. Rev. Neurosci. 2007, 8, 499-509. [CrossRef] [PubMed]

7. Sannerud, R.; Esselens, C.; Ejsmont, P.; Mattera, R.; Rochin, L.; Tharkeshwar, A.K.; De Baets, G.; De Wever, V.; Habets, R.; Baert, V. Restricted location of PSEN2/ $\gamma$-secretase determines substrate specificity and generates an intracellular A $\beta$ pool. Cell 2016, 166, 193-208. [CrossRef] [PubMed] 
8. Esbjörner, E.K.; Chan, F.; Rees, E.; Erdelyi, M.; Luheshi, L.M.; Bertoncini, C.W.; Kaminski, C.F.; Dobson, C.M.; Schierle, G.S.K. Direct observations of amyloid $\beta$ self-assembly in live cells provide insights into differences in the kinetics of $\mathrm{A} \beta(1-40)$ and $\mathrm{A} \beta$ (1-42) aggregation. Chem. Biol. 2014, 21, 732-742. [CrossRef] [PubMed]

9. Gouras, G.K.; Tsai, J.; Naslund, J.; Vincent, B.; Edgar, M.; Checler, F.; Greenfield, J.P.; Haroutunian, V.; Buxbaum, J.D.; Xu, H. Intraneuronal A $\beta 42$ accumulation in human brain. Am. J. Pathol. 2000, 156, 15-20. [CrossRef]

10. Jarrett, J.T.; Berger, E.P.; Lansbury, P.T., Jr. The carboxy terminus of the. beta. amyloid protein is critical for the seeding of amyloid formation: Implications for the pathogenesis of Alzheimer's disease. Biochemistry 1993, 32, 4693-4697. [CrossRef] [PubMed]

11. Murphy, M.P.; LeVine, H., III. Alzheimer's disease and the amyloid- $\beta$ peptide. J. Alzheimer's Dis. 2010, 19, 311-323. [CrossRef] [PubMed]

12. Linse, S. Monomer-dependent secondary nucleation in amyloid formation. Biophys. Rev. 2017, 9, 329-338. [CrossRef] [PubMed]

13. Meisl, G.; Yang, X.; Frohm, B.; Knowles, T.P.; Linse, S. Quantitative analysis of intrinsic and extrinsic factors in the aggregation mechanism of Alzheimer-associated A $\beta$-peptide. Sci. Rep. 2016, 6, 18728. [CrossRef] [PubMed]

14. Cohen, S.I.; Linse, S.; Luheshi, L.M.; Hellstrand, E.; White, D.A.; Rajah, L.; Otzen, D.E.; Vendruscolo, M.; Dobson, C.M.; Knowles, T.P. Proliferation of amyloid- $\beta 42$ aggregates occurs through a secondary nucleation mechanism. Proc. Natl. Acad. Sci. USA 2013, 110, 9758-9763. [CrossRef] [PubMed]

15. Arosio, P.; Michaels, T.C.; Linse, S.; Månsson, C.; Emanuelsson, C.; Presto, J.; Johansson, J.; Vendruscolo, M.; Dobson, C.M.; Knowles, T.P. Kinetic analysis reveals the diversity of microscopic mechanisms through which molecular chaperones suppress amyloid formation. Nat. Commun. 2016, 7, 10948. [CrossRef]

16. Munke, A.; Persson, J.; Weiffert, T.; De Genst, E.; Meisl, G.; Arosio, P.; Carnerup, A.; Dobson, C.M.; Vendruscolo, M.; Knowles, T.P. Phage display and kinetic selection of antibodies that specifically inhibit amyloid self-replication. Proc. Natl. Acad. Sci. USA 2017, 114, 6444-6449. [CrossRef] [PubMed]

17. Limbocker, R.; Chia, S.; Ruggeri, F.S.; Perni, M.; Cascella, R.; Heller, G.T.; Meisl, G.; Mannini, B.; Habchi, J.; Michaels, T.C. Trodusquemine enhances A $\beta 42$ aggregation but suppresses its toxicity by displacing oligomers from cell membranes. Nat. Commun. 2019, 10, 225. [CrossRef] [PubMed]

18. Lindberg, D.J.; Wesén, E.; Björkeroth, J.; Rocha, S.; Esbjörner, E.K. Lipid membranes catalyse the fibril formation of the amyloid- $\beta$ (1-42) peptide through lipid-fibril interactions that reinforce secondary pathways. Biochim. Biophys. Acta (BBA)-Biomembr. 2017, 1859, 1921-1929. [CrossRef]

19. Bush, A.I. The metallobiology of Alzheimer's disease. Trends Neurosci. 2003, 26, 207-214. [CrossRef]

20. Li, F.; Calingasan, N.Y.; Yu, F.; Mauck, W.M.; Toidze, M.; Almeida, C.G.; Takahashi, R.H.; Carlson, G.A.; Flint Beal, M.; Lin, M.T. Increased plaque burden in brains of APP mutant MnSOD heterozygous knockout mice. J. Neurochem. 2004, 89, 1308-1312. [CrossRef]

21. Smith, D.G.; Cappai, R.; Barnham, K.J. The redox chemistry of the Alzheimer's disease amyloid $\beta$ peptide. Biochim. Biophys. Acta (BBA)-Biomembr. 2007, 1768, 1976-1990. [CrossRef]

22. Huang, X.; Atwood, C.S.; Hartshorn, M.A.; Multhaup, G.; Goldstein, L.E.; Scarpa, R.C.; Cuajungco, M.P.; Gray, D.N.; Lim, J.; Moir, R.D. The A $\beta$ peptide of Alzheimer's disease directly produces hydrogen peroxide through metal ion reduction. Biochemistry 1999, 38, 7609-7616. [CrossRef] [PubMed]

23. Huang, X.; Moir, R.D.; Tanzi, R.E.; Bush, A.I.; Rogers, J.T. Redox-active metals, oxidative stress, and Alzheimer's disease pathology. Ann. N. Y. Acad. Sci. 2004, 1012, 153-163. [CrossRef]

24. Atwood, C.S.; Moir, R.D.; Huang, X.; Scarpa, R.C.; Bacarra, N.M.E.; Romano, D.M.; Hartshorn, M.A.; Tanzi, R.E.; Bush, A.I. Dramatic aggregation of Alzheimer $\mathrm{A} \beta$ by $\mathrm{Cu}$ (II) is induced by conditions representing physiological acidosis. J. Biol. Chem. 1998, 273, 12817-12826. [CrossRef] [PubMed]

25. Bush, A.I.; Pettingell, W.H.; Multhaup, G.; d Paradis, M.; Vonsattel, J.-P.; Gusella, J.F.; Beyreuther, K.; Masters, C.L.; Tanzi, R.E. Rapid induction of Alzheimer A beta amyloid formation by zinc. Science 1994, 265, 1464-1467. [CrossRef] [PubMed]

26. Esler, W.P.; Stimson, E.R.; Jennings, J.M.; Ghilardi, J.R.; Mantyh, P.W.; Maggio, J.E. Zinc-induced aggregation of human and rat $\beta$-amyloid peptides in vitro. J. Neurochem. 1996, 66, 723-732. [CrossRef]

27. Mantyh, P.W.; Ghilardi, J.R.; Rogers, S.; DeMaster, E.; Allen, C.J.; Stimson, E.R.; Maggio, J.E. Aluminum, iron, and zinc ions promote aggregation of physiological concentrations of $\beta$-amyloid peptide. J. Neurochem. 1993, 61, 1171-1174. [CrossRef] [PubMed] 
28. Beauchemin, D.; Kisilevsky, R. A method based on ICP-MS for the analysis of Alzheimer's amyloid plaques. Anal. Chem. 1998, 70, 1026-1029. [CrossRef] [PubMed]

29. Dong, J.; Atwood, C.S.; Anderson, V.E.; Siedlak, S.L.; Smith, M.A.; Perry, G.; Carey, P.R. Metal binding and oxidation of amyloid- $\beta$ within isolated senile plaque cores: Raman microscopic evidence. Biochemistry 2003, 42, 2768-2773. [CrossRef]

30. Miller, L.M.; Wang, Q.; Telivala, T.P.; Smith, R.J.; Lanzirotti, A.; Miklossy, J. Synchrotron-based infrared and X-ray imaging shows focalized accumulation of $\mathrm{Cu}$ and $\mathrm{Zn}$ co-localized with $\beta$-amyloid deposits in Alzheimer's disease. J. Struct. Biol. 2006, 155, 30-37. [CrossRef]

31. Curtain, C.C.; Ali, F.; Volitakis, I.; Cherny, R.A.; Norton, R.S.; Beyreuther, K.; Barrow, C.J.; Masters, C.L.; Bush, A.I.; Barnham, K.J. Alzheimer's disease amyloid- $\beta$ binds copper and zinc to generate an allosterically ordered membrane-penetrating structure containing superoxide dismutase-like subunits. J. Biol. Chem. 2001, 276, 20466-20473. [CrossRef] [PubMed]

32. Huang, X.; Cuajungco, M.P.; Atwood, C.S.; Hartshorn, M.A.; Tyndall, J.D.; Hanson, G.R.; Stokes, K.C.; Leopold, M.; Multhaup, G.; Goldstein, L.E. Cu (II) potentiation of Alzheimer A $\beta$ neurotoxicity correlation with cell-free hydrogen peroxide production and metal reduction. J. Biol. Chem. 1999, 274, 37111-37116. [CrossRef] [PubMed]

33. Opazo, C.; Huang, X.; Cherny, R.A.; Moir, R.D.; Roher, A.E.; White, A.R.; Cappai, R.; Masters, C.L.; Tanzi, R.E.; Inestrosa, N.C. Metalloenzyme-like activity of Alzheimer's disease $\beta$-amyloid Cu-dependent catalytic conversion of dopamine, cholesterol, and biological reducing agents to neurotoxic H2O2. J. Biol. Chem. 2002, 277, 40302-40308. [CrossRef] [PubMed]

34. Reybier, K.; Ayala, S.; Alies, B.; Rodrigues, J.V.; Bustos Rodriguez, S.; La Penna, G.; Collin, F.; Gomes, C.M.; Hureau, C.; Faller, P. Free Superoxide is an Intermediate in the Production of H2O2 by Copper (I)-A $\beta$ Peptide and O2. Angew. Chem. Int. Ed. 2016, 55, 1085-1089. [CrossRef] [PubMed]

35. Guilloreau, L.; Combalbert, S.; Sournia-Saquet, A.; Mazarguil, H.; Faller, P. Redox Chemistry of Copper-Amyloid- $\beta$ : The Generation of Hydroxyl Radical in the Presence of Ascorbate is Linked to Redox-Potentials and Aggregation State. ChemBioChem 2007, 8, 1317-1325. [CrossRef] [PubMed]

36. Mathys, Z.K.; White, A.R. Copper and Alzheimer's Disease. In Neurotoxicity of Metals; Springer: Berlin/Heidelberg, Germany, 2017; pp. 199-216.

37. Santos, M.A.; Chand, K.; Chaves, S. Recent progress in multifunctional metal chelators as potential drugs for Alzheimer's disease. Coord. Chem. Rev. 2016, 327, 287-303. [CrossRef]

38. Matlack, K.E.; Tardiff, D.F.; Narayan, P.; Hamamichi, S.; Caldwell, K.A.; Caldwell, G.A.; Lindquist, S. Clioquinol promotes the degradation of metal-dependent amyloid- $\beta(\mathrm{A} \beta)$ oligomers to restore endocytosis and ameliorate A $\beta$ toxicity. Proc. Natl. Acad. Sci. USA 2014, 111, 4013-4018. [CrossRef] [PubMed]

39. Adlard, P.A.; Bush, A.I. Metals and Alzheimer's disease. J. Alzheimer's Dis. 2006, 10, 145-163. [CrossRef] [PubMed]

40. Deibel, M.; Ehmann, W.; Markesbery, W. Copper, iron, and zinc imbalances in severely degenerated brain regions in Alzheimer's disease: Possible relation to oxidative stress. J. Neurol. Sci. 1996, 143, 137-142. [CrossRef]

41. Squitti, R.; Ghidoni, R.; Simonelli, I.; Ivanova, I.D.; Colabufo, N.A.; Zuin, M.; Benussi, L.; Binetti, G.; Cassetta, E.; Rongioletti, M. Copper dyshomeostasis in Wilson disease and Alzheimer's disease as shown by serum and urine copper indicators. J. Trace Elem. Med. Biol. 2018, 45, 181-188. [CrossRef]

42. Xu, J.; Begley, P.; Church, S.J.; Patassini, S.; McHarg, S.; Kureishy, N.; Hollywood, K.A.; Waldvogel, H.J.; Liu, H.; Zhang, S. Elevation of brain glucose and polyol-pathway intermediates with accompanying brain-copper deficiency in patients with Alzheimer's disease: Metabolic basis for dementia. Sci. Rep. 2016, 6, 27524. [CrossRef] [PubMed]

43. Austin, C.D.; Wen, X.; Gazzard, L.; Nelson, C.; Scheller, R.H.; Scales, S.J. Oxidizing potential of endosomes and lysosomes limits intracellular cleavage of disulfide-based antibody-drug conjugates. Proc. Natl. Acad. Sci. USA 2005, 102, 17987-17992. [CrossRef] [PubMed]

44. Bolognin, S.; Messori, L.; Drago, D.; Gabbiani, C.; Cendron, L.; Zatta, P. Aluminum, copper, iron and zinc differentially alter amyloid-A $\beta 1-42$ aggregation and toxicity. Int. J. Biochem. Cell Biol. 2011, 43, 877-885. [CrossRef] [PubMed] 
45. Brzyska, M.; Trzesniewska, K.; Wieckowska, A.; Szczepankiewicz, A.; Elbaum, D. Electrochemical and Conformational Consequences of Copper (CuI and CuII) Binding to $\beta$-Amyloid (1-40). ChemBioChem 2009, 10, 1045-1055. [CrossRef]

46. Dai, X.; Sun, Y.; Gao, Z.; Jiang, Z. Copper enhances amyloid- $\beta$ peptide neurotoxicity and non $\beta$-aggregation: A series of experiments conducted upon copper-bound and copper-free amyloid- $\beta$ peptide. J. Mol. Neurosci. 2010, 41, 66-73. [CrossRef] [PubMed]

47. House, E.; Mold, M.; Collingwood, J.; Baldwin, A.; Goodwin, S.; Exley, C. Copper Abolishes the $\beta$-Sheet Secondary Structure of Preformed Amyloid Fibrils of Amyloid- $\beta$ 42. J. Alzheimer's Dis. 2009, 18, 811-817. [CrossRef]

48. Mold, M.; Ouro-Gnao, L.; Wieckowski, B.M.; Exley, C. Copper prevents amyloid- $\beta$ 1-42 from forming amyloid fibrils under near-physiological conditions in vitro. Sci. Rep. 2013, 3, 1256. [CrossRef]

49. Yoshiike, Y.; Tanemura, K.; Murayama, O.; Akagi, T.; Murayama, M.; Sato, S.; Sun, X.; Tanaka, N.; Takashima, A. New insights on how metals disrupt amyloid $\beta$-aggregation and their effects on amyloid- $\beta$ cytotoxicity. J. Biol. Chem. 2001, 276, 32293-32299. [CrossRef]

50. Zou, J.; Kajita, K.; Sugimoto, N. Cu2+ Inhibits the Aggregation of Amyloid $\beta$-Peptide (1-42) in vitro. Angew. Chem. Int. Ed. 2001, 40, 2274-2277. [CrossRef]

51. Abelein, A.; Gräslund, A.; Danielsson, J. Zinc as chaperone-mimicking agent for retardation of amyloid $\beta$ peptide fibril formation. Proc. Natl. Acad. Sci. USA 2015, 112, 5407-5412. [CrossRef]

52. Gu, M.; Bode, D.C.; Viles, J.H. Copper redox cycling inhibits $A \beta$ fibre formation and promotes fibre fragmentation, while generating a dityrosine A $\beta$ dimer. Sci. Rep. 2018, 8, 1-14. [CrossRef] [PubMed]

53. Sarell, C.J.; Wilkinson, S.R.; Viles, J.H. Substoichiometric levels of $\mathrm{Cu} 2+$ ions accelerate the kinetics of fiber formation and promote cell toxicity of amyloid- $\beta$ from Alzheimer disease. J. Biol. Chem. 2010, 285, 41533-41540. [CrossRef] [PubMed]

54. Smith, D.P.; Ciccotosto, G.D.; Tew, D.J.; Fodero-Tavoletti, M.T.; Johanssen, T.; Masters, C.L.; Barnham, K.J.; Cappai, R. Concentration dependent $\mathrm{Cu} 2+$ induced aggregation and dityrosine formation of the Alzheimer's disease amyloid- $\beta$ peptide. Biochemistry 2007, 46, 2881-2891. [CrossRef] [PubMed]

55. Sharma, A.K.; Pavlova, S.T.; Kim, J.; Kim, J.; Mirica, L.M. The effect of Cu 2+ and Zn 2+ on the A $\beta 42$ peptide aggregation and cellular toxicity. Metallomics 2013, 5, 1529-1536. [CrossRef] [PubMed]

56. Yang, J.; Zhang, X.; Zhu, Y.; Lenczowski, E.; Tian, Y.; Yang, J.; Zhang, C.; Hardt, M.; Qiao, C.; Tanzi, R.E. The double-edged role of copper in the fate of amyloid beta in the presence of anti-oxidants. Chem. Sci. 2017, 8, 6155-6164. [CrossRef] [PubMed]

57. Du, X.; Wang, Z.; Zheng, Y.; Li, H.; Ni, J.; Liu, Q. Inhibitory effect of selenoprotein P on Cu+/Cu2+-induced A $\beta 42$ aggregation and toxicity. Inorg. Chem. 2014, 53, 1672-1678. [CrossRef]

58. Faller, P.; Hureau, C. Bioinorganic chemistry of copper and zinc ions coordinated to amyloid- $\beta$ peptide. Dalton Trans. 2009, 1080-1094. [CrossRef]

59. Garzon-Rodriguez, W.; Yatsimirsky, A.K.; Glabe, C.G. Binding of Zn (II), Cu (II), and Fe (II) ions to alzheimer's Aß peptide studied by fluorescence. Bioorganic Med. Chem. Lett. 1999, 9, 2243-2248. [CrossRef]

60. Guilloreau, L.; Damian, L.; Coppel, Y.; Mazarguil, H.; Winterhalter, M.; Faller, P. Structural and thermodynamical properties of $\mathrm{Cu}$ II amyloid- $\beta 16 / 28$ complexes associated with Alzheimer's disease. JBIC J. Biol. Inorg. Chem. 2006, 11, 1024-1038. [CrossRef]

61. Jiang, D.; Men, L.; Wang, J.; Zhang, Y.; Chickenyen, S.; Wang, Y.; Zhou, F. Redox reactions of copper complexes formed with different $\beta$-amyloid peptides and their neuropathalogical relevance. Biochemistry 2007, 46, 9270-9282. [CrossRef]

62. Tõugu, V.; Tiiman, A.; Palumaa, P. Interactions of Zn (II) and Cu (II) ions with Alzheimer's amyloid-beta peptide. Metal ion binding, contribution to fibrillization and toxicity. Metallomics 2011, 3, 250-261. [CrossRef]

63. Karr, J.W.; Szalai, V.A. Cu (II) binding to monomeric, oligomeric, and fibrillar forms of the Alzheimer's disease amyloid- $\beta$ peptide. Biochemistry 2008, 47, 5006-5016. [CrossRef] [PubMed]

64. Sarell, C.J.; Syme, C.D.; Rigby, S.E.; Viles, J.H. Copper (II) binding to amyloid- $\beta$ fibrils of Alzheimer's disease reveals a picomolar affinity: Stoichiometry and coordination geometry are independent of $A \beta$ oligomeric form. Biochemistry 2009, 48, 4388-4402. [CrossRef] [PubMed]

65. Shearer, J.; Szalai, V.A. The amyloid- $\beta$ peptide of Alzheimer's disease binds CuI in a linear bis-his coordination environment: Insight into a possible neuroprotective mechanism for the amyloid- $\beta$ peptide. J. Am. Chem. Soc. 2008, 130, 17826-17835. [CrossRef] [PubMed] 
66. Syme, C.D.; Nadal, R.C.; Rigby, S.E.; Viles, J.H. Copper Binding to the Amyloid- $\beta$ (A $\beta$ ) Peptide Associated with Alzheimer's Disease Folding, Coordination Geometry, ph Dependence, Stoichiometry, and Affinity of a $3-(1-28)$ : Insights from a Range of Complementary Spectroscopic Techniques. J. Biol. Chem. 2004, 279, 18169-18177. [CrossRef]

67. Bin, Y.; Chen, S.; Xiang, J.pH-dependent kinetics of copper ions binding to amyloid- $\beta$ peptide. J. Inorg. Biochem. 2013, 119, 21-27. [CrossRef]

68. Ma, Q.F.; Hu, J.; Wu, W.H.; Liu, H.D.; Du, J.T.; Fu, Y.; Wu, Y.W.; Lei, P.; Zhao, Y.F.; Li, Y.M. Characterization of copper binding to the peptide amyloid- $\beta$ (1-16) associated with Alzheimer's disease. Biopolym. Orig. Res. Biomol. 2006, 83, 20-31. [CrossRef]

69. Yako, N.; Young, T.R.; Jones, J.M.C.; Hutton, C.A.; Wedd, A.G.; Xiao, Z. Copper binding and redox chemistry of the $A \beta 16$ peptide and its variants: Insights into determinants of copper-dependent reactivity. Metallomics 2017, 9, 278-291. [CrossRef]

70. Atwood, C.S.; Scarpa, R.C.; Huang, X.; Moir, R.D.; Jones, W.D.; Fairlie, D.P.; Tanzi, R.E.; Bush, A.I. Characterization of Copper Interactions with Alzheimer Amyloid $\beta$ Peptides: Identification of an Attomolar-Affinity Copper Binding Site on Amyloid B1-42. J. Neurochem. 2000, 75, 1219-1233. [CrossRef]

71. Lawrence, R.E.; Zoncu, R. The lysosome as a cellular centre for signalling, metabolism and quality control. Nat. Cell Biol. 2019, 21, 133-142. [CrossRef] [PubMed]

72. Furlan, S.; Hureau, C.; Faller, P.; La Penna, G. Modeling the $\mathrm{Cu}+$ Binding in the $1-16$ Region of the Amyloid- $\beta$ Peptide Involved in Alzheimer's Disease. J. Phys. Chem. B 2010, 114, 15119-15133. [CrossRef]

73. Colvin, M.T.; Silvers, R.; Ni, Q.Z.; Can, T.V.; Sergeyev, I.; Rosay, M.; Donovan, K.J.; Michael, B.; Wall, J.; Linse, S. Atomic resolution structure of monomorphic A 342 amyloid fibrils. J. Am. Chem. Soc. 2016, 138, 9663-9674. [CrossRef] [PubMed]

74. Wälti, M.A.; Ravotti, F.; Arai, H.; Glabe, C.G.; Wall, J.S.; Böckmann, A.; Güntert, P.; Meier, B.H.; Riek, R. Atomic-resolution structure of a disease-relevant A $\beta$ (1-42) amyloid fibril. Proc. Natl. Acad. Sci. USA 2016, 113, E4976-E4984. [CrossRef] [PubMed]

75. Hellstrand, E.; Boland, B.; Walsh, D.M.; Linse, S. Amyloid $\beta$-protein aggregation produces highly reproducible kinetic data and occurs by a two-phase process. ACS Chem. Neurosci. 2010, 1, 13-18. [CrossRef] [PubMed]

76. Abelein, A.; Chen, G.; Kitoka, K.; Aleksis, R.; Oleskovs, F.; Sarr, M.; Landreh, M.; Pahnke, J.; Nordling, K.; Kronqvist, N. High-yield Production of Amyloid- $\beta$ Peptide Enabled by a Customized Spider Silk Domain. Sci. Rep. 2020, 10, 1-10. [CrossRef] [PubMed]

77. Kronqvist, N.; Sarr, M.; Lindqvist, A.; Nordling, K.; Otikovs, M.; Venturi, L.; Pioselli, B.; Purhonen, P.; Landreh, M.; Biverstål, H. Efficient protein production inspired by how spiders make silk. Nat. Commun. 2017, 8, 1-15. [CrossRef] [PubMed]

78. Tropea, J.E.; Cherry, S.; Waugh, D.S. Expression and Purification of Soluble His 6-tagged TEV Protease. In High Throughput Protein Expression and Purification; Springer: Berlin/Heidelberg, Germany, 2009; pp. 297-307.

79. Cohen, S.I.; Arosio, P.; Presto, J.; Kurudenkandy, F.R.; Biverstål, H.; Dolfe, L.; Dunning, C.; Yang, X.; Frohm, B.; Vendruscolo, M. A molecular chaperone breaks the catalytic cycle that generates toxic A $\beta$ oligomers. Nat. Struct. Mol. Biol. 2015, 22, 207. [CrossRef]

80. Scheidt, T.; Łapińska, U.; Kumita, J.R.; Whiten, D.R.; Klenerman, D.; Wilson, M.R.; Cohen, S.I.; Linse, S.; Vendruscolo, M.; Dobson, C.M. Secondary nucleation and elongation occur at different sites on Alzheimer's amyloid- $\beta$ aggregates. Sci. Adv. 2019, 5, eaau3112. [CrossRef] [PubMed]

81. Niemiec, M.S.; Dingeldein, A.P.; Wittung-Stafshede, P. T versus D in the MTCXXC motif of copper transport proteins plays a role in directional metal transport. JBIC J. Biol. Inorg. Chem. 2014, 19, 1037-1047. [CrossRef] [PubMed]

82. Niemiec, M.S.; Dingeldein, A.P.; Wittung-Stafshede, P. Enthalpy-entropy compensation at play in human copper ion transfer. Sci. Rep. 2015, 5, 10518. [CrossRef] [PubMed]

83. Niemiec, M.S.; Weise, C.F.; Wittung-Stafshede, P. In vitro thermodynamic dissection of human copper transfer from chaperone to target protein. PLoS ONE 2012, 7, e36102. [CrossRef] [PubMed]

84. Knowles, T.P.; Waudby, C.A.; Devlin, G.L.; Cohen, S.I.; Aguzzi, A.; Vendruscolo, M.; Terentjev, E.M.; Welland, M.E.; Dobson, C.M. An analytical solution to the kinetics of breakable filament assembly. Science 2009, 326, 1533-1537. [CrossRef] [PubMed] 
85. Meisl, G.; Kirkegaard, J.B.; Arosio, P.; Michaels, T.C.; Vendruscolo, M.; Dobson, C.M.; Linse, S.; Knowles, T.P. Molecular mechanisms of protein aggregation from global fitting of kinetic models. Nat. Protoc. 2016, 11, 252. [CrossRef]

86. Kayed, R.; Head, E.; Sarsoza, F.; Saing, T.; Cotman, C.W.; Necula, M.; Margol, L.; Wu, J.; Breydo, L.; Thompson, J.L. Fibril specific, conformation dependent antibodies recognize a generic epitope common to amyloid fibrils and fibrillar oligomers that is absent in prefibrillar oligomers. Mol. Neurodegener. 2007, 2, 18. [CrossRef] [PubMed]

87. Indi, S.; Rao, K. Copper-and iron-induced differential fibril formation in $\alpha$-synuclein: TEM study. Neurosci. Lett. 2007, 424, 78-82.

88. Levine, H., III. Thioflavine T interaction with synthetic Alzheimer's disease $\beta$-amyloid peptides: Detection of amyloid aggregation in solution. Protein Sci. 1993, 2, 404-410. [CrossRef] [PubMed]

89. Lindberg, D.J.; Wranne, M.S.; Gatty, M.G.; Westerlund, F.; Esbjörner, E.K. Steady-state and time-resolved Thioflavin-T fluorescence can report on morphological differences in amyloid fibrils formed by A $\beta$ (1-40) and A $\beta$ (1-42). Biochem. Biophys. Res. Commun. 2015, 458, 418-423. [CrossRef] [PubMed]

90. Jun, S.; Saxena, S. The Aggregated State of Amyloid- $\beta$ Peptide In Vitro Depends on Cu2+ Ion Concentration. Angew. Chem. Int. Ed. 2007, 46, 3959-3961. [CrossRef]

91. Klement, K.; Wieligmann, K.; Meinhardt, J.; Hortschansky, P.; Richter, W.; Fändrich, M. Effect of different salt ions on the propensity of aggregation and on the structure of Alzheimer's A $\beta$ (1-40) amyloid fibrils. J. Mol. Biol. 2007, 373, 1321-1333. [CrossRef]

92. Lindberg, D.J.; Esbjörner, E.K. Detection of amyloid- $\beta$ fibrils using the DNA-intercalating dye YOYO-1: Binding mode and fibril formation kinetics. Biochem. Biophys. Res. Commun. 2016, 469, 313-318. [CrossRef]

93. Meisl, G.; Yang, X.; Dobson, C.M.; Linse, S.; Knowles, T.P. Modulation of electrostatic interactions to reveal a reaction network unifying the aggregation behaviour of the $\mathrm{A} \beta 42$ peptide and its variants. Chem. Sci. 2017, 8, 4352-4362. [CrossRef]

94. Antzutkin, O.N. Amyloidosis of Alzheimer's A $\beta$ peptides: Solid-state nuclear magnetic resonance, electron paramagnetic resonance, transmission electron microscopy, scanning transmission electron microscopy and atomic force microscopy studies. Magn. Reson. Chem. 2004, 42, 231-246. [CrossRef] [PubMed]

95. Wesén, E.; Jeffries, G.D.; Dzebo, M.M.; Esbjörner, E.K. Endocytic uptake of monomeric amyloid- $\beta$ peptides is clathrin-and dynamin-independent and results in selective accumulation of $A \beta(1-42)$ compared to A $\beta$ (1-40). Sci. Rep. 2017, 7, 1-14. [CrossRef]

96. Törnquist, M.; Michaels, T.C.; Sanagavarapu, K.; Yang, X.; Meisl, G.; Cohen, S.I.; Knowles, T.P.; Linse, S. Secondary nucleation in amyloid formation. Chem. Commun. 2018, 54, 8667-8684. [CrossRef] [PubMed]

97. Cohen, S.I.; Vendruscolo, M.; Dobson, C.M.; Knowles, T.P. From macroscopic measurements to microscopic mechanisms of protein aggregation. J. Mol. Biol. 2012, 421, 160-171. [CrossRef] [PubMed]

98. Bacci, M.; Vymětal, J.í; Mihajlovic, M.; Caflisch, A.; Vitalis, A. Amyloid $\beta$ fibril elongation by monomers involves disorder at the tip. J. Chem. Theory Comput. 2017, 13, 5117-5130. [CrossRef] [PubMed]

99. Cannon, M.J.; Williams, A.D.; Wetzel, R.; Myszka, D.G. Kinetic analysis of beta-amyloid fibril elongation. Anal. Biochem. 2004, 328, 67-75. [CrossRef] [PubMed]

100. Vettore, N.; Buell, A.K. Thermodynamics of amyloid fibril formation from chemical depolymerization. Phys. Chem. Chem. Phys. 2019, 21, 26184-26194. [CrossRef] [PubMed]

101. Gurry, T.; Stultz, C.M. Mechanism of amyloid- $\beta$ fibril elongation. Biochemistry 2014, 53, 6981-6991. [CrossRef] [PubMed]

102. Feaga, H.A.; Maduka, R.C.; Foster, M.N.; Szalai, V.A. Affinity of Cu+ for the copper-binding domain of the amyloid- $\beta$ peptide of Alzheimer's disease. Inorg. Chem. 2011, 50, 1614-1618. [CrossRef] [PubMed]

(C) 2020 by the authors. Licensee MDPI, Basel, Switzerland. This article is an open access article distributed under the terms and conditions of the Creative Commons Attribution (CC BY) license (http://creativecommons.org/licenses/by/4.0/). 